Article

\title{
Extracellular Redox Regulation of $\alpha 7 \beta$ Integrin-Mediated Cell Migration Is Signaled via a Dominant Thiol-Switch
}

Lukas Bergerhausen ${ }^{1,+}$, Julius Grosche ${ }^{1, \dagger}{ }^{\text {, Juliane Meißner }}{ }^{1,+}$, Christina Hecker ${ }^{2}$, Michele F. Caliandro ${ }^{1}$, Christoph Westerhausen ${ }^{3,4}$, Andrej Kamenac ${ }^{3}{ }^{(1)}$, Maryam Rezaei ${ }^{1}$, Matthias Mörgelin ${ }^{5}$, Gereon Poschmann ${ }^{6}$, Dietmar Vestweber ${ }^{7}$, Eva-Maria Hanschmann ${ }^{2}$ (I) and Johannes A. Eble ${ }^{1, *(1)}$

1 Institute of Physiological Chemistry and Pathobiochemistry, University of Münster, 48149 Münster, Germany; lukas.bergerhausen@googlemail.com (L.B.); julius.grosche@googlemail.com (J.G.); juliane_meissner@gmx.net (J.M.); caliandromichelefabrizio@gmail.com (M.F.C.); mar.rezaei80@gmail.com (M.R.)

2 Department of Neurology, Medical Faculty, Heinrich-Heine University Düsseldorf, 40225 Düsseldorf, Germany; Christina.Hecker@uni-duesseldorf.de (C.H.); eva_hanschmann@web.de (E.-M.H.)

3 Biophysics Group, Department of Experimental Physics, Institute of Physics, University of Augsburg, 86159 Augsburg, Germany; christoph.westerhausen@gmail.com (C.W.);

andrej.kamenac@physik.uni-augsburg.de (A.K.)

4 Institute of Theoretical Medicine, University of Augsburg, 86159 Augsburg, Germany

5 Colzyx AB, 22381 Lund, Sweden; matthias@colzyx.com

6 Institute of Molecular Medicine I, Functional Redox Proteomics, Heinrich-Heine University Düsseldorf, 40225 Düsseldorf, Germany; gereon.poschmann@hhu.de

7 Department of Vascular Cell Biology, Max Planck-Institute of Molecular Biomedicine, 48149 Münster, Germany; vestweb@mpi-muenster.mpg.de

* Correspondence: eblej@uni-muenster.de; Tel.: +49-251-835-5591

+ The authors contributed equally.

Received: 18 February 2020; Accepted: 8 March 2020; Published: 10 March 2020

\begin{abstract}
While adhering to extracellular matrix (ECM) proteins, such as laminin-111, cells temporarily produce hydrogen peroxide at adhesion sites. To study the redox regulation of $\alpha 7 \beta 1$ integrin-mediated cell adhesion to laminin-111, a conserved cysteine pair within the $\alpha$-subunit hinge region was replaced for alanines. The molecular and cellular effects were analyzed by electron and atomic force microscopy, impedance-based migration assays, flow cytometry and live cell imaging. This cysteine pair constitutes a thiol-switch, which redox-dependently governs the equilibrium between an extended and a bent integrin conformation with high and low ligand binding activity, respectively. Hydrogen peroxide oxidizes the cysteines to a disulfide bond, increases ligand binding and promotes cell migration toward laminin-111. Inversely, extracellular thioredoxin-1 reduces the disulfide, thereby decreasing laminin binding. Mutation of this cysteine pair into the non-oxidizable hinge-mutant shows molecular and cellular effects similar to the reduced wild-type integrin, but lacks redox regulation. This proves the existence of a dominant thiol-switch within the $\alpha$ subunit hinge of $\alpha 7 \beta 1$ integrin, which is sufficient to implement activity regulation by extracellular redox agents in a redox-regulatory circuit. Our data reveal a novel and physiologically relevant thiol-based regulatory mechanism of integrin-mediated cell-ECM interactions, which employs short-lived hydrogen peroxide and extracellular thioredoxin-1 as signaling mediators.
\end{abstract}

Keywords: redox regulation; redox signaling; integrin $\alpha 7 \beta 1$; thiol-switch; extracellular thioredoxin- 1 ; laminin binding; cell migration 


\section{Introduction}

During cell movement and tissue remodeling, cells exert forces onto the extracellular matrix (ECM). Laminins are key components within basement membranes, sheet-like ECM scaffolds, which also surround muscle cells and fibers [1]. Laminin-111 contributes to mechanical force transduction between muscle cells and the ECM [2]. Force-transmitting cell contacts to the laminin network are mediated inter alia via integrins $[3,4]$. These cell adhesion molecules consist of two subunits, $\alpha$ and $\beta$. Their $\mathrm{N}$-terminal extracellular domains jointly form the ligand binding head domain, which is connected via two stalks to the transmembrane and short cytoplasmic domains of each chain [3]. Integrins change between a bent, an extended close and extended open conformation [3,5]. The transition from the bent to the extended conformation is a rotation of the head and stalk domains relative to each other around a pivot. This pivot is formed by peptide loops between the EGF-domains 1 and 2 of the $\beta$-subunit and between the thigh and calf- 1 domains of the $\alpha$-subunit. This hinge region of the integrin $\alpha$ subunit contains a pair of cysteines, which, if crosslinked via a disulfide bridge, encompasses a peptide loop of five amino acids. [3]. The bent and extended integrin conformations are distinguished with conformation-dependent antibodies, such as the monoclonal antibody (mAb) 9EG7, whose epitope within the $\beta 1$ integrin subunit is accessible only in the extended conformation [6,7]. Transition of the extended close to the extended open conformation is a separational move of the stalks of both integrin subunits $[3,5]$. The extended open conformation binds the ECM ligand with highest activity, while ligand binding activity decreases along the extended close to the bent conformation [3,5]. Binding of ECM ligands to integrins not only anchors the cell mechanically but also transmits environmental cues and signals into the cell [8]. Moreover, integrins are part of a complex regulatory network encompassing other proteins of the adhesion sites and growth factor receptors $[9,10]$.

Four members of the integrin family recognize laminins albeit with isoform-dependent affinities [4]. Integrin $\alpha 3 \beta 1$ preferentially binds laminin-322 and laminin-511, but not laminin-111 [11]. In contrast, $\alpha 6 \beta 1, \alpha 6 \beta 4$ and $\alpha 7 \beta 1$ bind laminin-111 [12,13]. Integrin $\alpha 7 \beta 1$ was first isolated from striated and smooth muscle tissue. Integrin $\alpha 7$ knockout mice suffer from muscle dystrophy and defects in neurite regeneration [14,15]. As an oncogenic marker, integrin $\alpha 7 \beta 1$ expression changes during tumorigenesis, such as in glioblastoma [16] and melanoma [17,18].

Integrins and their ECM ligands are targets of reactive oxygen species (ROS) (reviewed in [19-21]). In a previous study, we identified six out of about 80 cysteines within integrin $\alpha 7 \beta 1$, which were selectively oxidized by hydrogen peroxide [22]. All of them are located within the integrin $\alpha 7$ subunit, two of which are located within the hinge region and four others within the calf- 2 domain. Therefore, we hypothesized that integrins are also subject to thiol-based redox regulation. This concept implies the existence of a thiol-switch consisting for instance of a pair of cysteines in close proximity [23]. Along with reversible disulfide bond formation, this cysteine pair changes the protein conformation and activity. Previous studies reported that specific cysteine residues within integrins, located within [24-26] and outside $[24,27-31]$ of the $\alpha$-subunit hinge region, are relevant for integrin function. However, most of these studies did not show their redox-dependent functional reversibility.

The concept of redox regulation implies a pair of oxidizing and reducing agents that forms and splits, respectively, the disulfide bridge within the redox-regulated integrin target. Upon initial contact with laminin-111, cells form redox hot spots in knob-like protrusions, where hydrogen peroxide is produced and the redox potential increases locally and transiently [22]. We surmised that the membrane-permeable hydrogen peroxide activates integrins for ligand binding. Previously, protein disulfide isomerases (PDIs) were reported to redox-modify integrins $[27,28]$. However, PDIs are isomerases, whereas only oxidoreductases transfer electrons from one molecule to another. Some oxidoreductases, including thioredoxin-1 (Trx1), were shown to be secreted [32,33]. They mediate rapid and reversible reduction of disulfide bonds and serve as key regulators of redox signaling circuits [23,32].

Here, we introduce a new redox circuit that regulates the conformation and ligand binding of $\alpha 7 \beta 1$ integrin. We delineate one specific pair of cysteines within the hinge region of the integrin $\alpha 7$ 
subunit that is oxidized by hydrogen peroxide and reduced by extracellular Trx1, and thus functions as a regulatory thiol switch in a dominant manner.

\section{Materials and Methods}

\subsection{Cell Culture}

Human fibrosarcoma HT1080 cells (ATCC, Manassas, VA, USA) and human embryonic kidney (HEK)-293T cells were cultured in DMEM/high glucose medium (Lonza, Basel, Switzerland) containing $10 \%(v / v)$ heat-inactivated fetal calf serum (FCS) (Gibco, Waltham, MA, USA), $100 \mathrm{U} / \mathrm{mL}$ penicillin and streptomycin (Gibco), at $37^{\circ} \mathrm{C}$ and $5 \%$ and $7 \% \mathrm{CO}_{2}$ (for HT1080 and HEK-293T cells, respectively). The HEK-293T cell medium was supplemented with $0.1 \mathrm{mM}$ nonessential amino acids (PAA Laboratories, Cölbe, Germany), $6 \mathrm{mM}$ L-glutamine (Gibco), and $1 \mathrm{mM}$ sodium pyruvate (PAA Laboratories). The Drosophila Schneider's cell line-2 was grown in SF-900 II SFM medium (Gibco) containing $10 \%(v / v)$ heat-inactivated FCS.

\subsection{Mutagenesis of Redox-Modifiable Cysteine Residues within Integrin $\alpha 7$ Subunit}

Cysteine-to-alanine mutations in the integrin $\alpha 7$ hinge and calf- 2 domains were introduced by MEGAWHOP-PCR. To this end, double-stranded DNA gene blocks (IDT, Skokie, IL, USA) encoding the $\alpha 7$ hinge ( $\alpha 7 \mathrm{hi}$ ) and $\alpha 7 \mathrm{calf}-2$ ( $\alpha 7 \mathrm{ca} 2)$ domain-spanning nucleotide sequences 1766-2133 and 3071-3374, respectively, of the mouse integrin ITGA7, splice variant $X 2$, including the mutated codons, were used as primers to replace the relevant cysteines for alanines. Thus, the pBSIISK-vector bearing integrin $\alpha 7 X 2$ cDNA (kindly provided by Dr. U. Mayer, University of Manchester, UK) [12] was PCR-amplified and mutated into pBSIISK- $\alpha$ 7hi and pBSIISK- $\alpha 7 \mathrm{ca} 2$, respectively. The double mutant $\alpha 7 \mathrm{hi}$-ca2 was generated by amplifying pBSIISK- $\alpha$ 7hi with the $\alpha 7$ calf-2 gene block. The cDNAs encoding the ITGA7 mutants were subcloned into pCR2.1 vector (Invitrogen, Carlsbad, CA, USA) via their flanking XbaI restriction sites.

\subsection{Construction of Expression Vectors pIRESneo3-a7 and pUC-hygMT-a7-Fos}

The soluble integrin ectodomains were heterodimerized with the zipper domains of Fos and Jun [11,12]. The Fos-zipper-encoding cDNA was PCR-amplified from pUC-hygMT-a3-Fos [11] with the primers, FOS fwd, 5'-CAT CAC CGG TGG GTCGAAC GGG CGG C-3' and FOS rev2, 5' -CCA CAC CTC CCC CTG AAC C- $3^{\prime}$. The amplicon was introduced into $\mathrm{pCR} 2.1-\alpha 7$ via an AgeI restriction site which had previously been introduced upstream of the transmembrane domain-encoding sequence with directed mutagenesis in an overlap extension PCR with the primers ABM fwd, $5^{\prime}$-AGG AGT ACA TGG CCG TGA AA- $3^{\prime}$, and ABM rev, $5^{\prime}$-CAC TAT AGG GCG AAT TGG GC- $3^{\prime}$. The mutagenesis primer pair was mut fwd, $5^{\prime}$-AGT CCC CAC CGG TGT CAT CCT CCT GG-3' , and mut rev, $5^{\prime}$-GGA TGA CAC CGG TGG GGA CTC CTT CC-3' (AgeI site underlined). The first PCRs (primer pairs: AMB fwd and mut rev; mut fwd and ABM rev) yielded 168 and $343 \mathrm{bp}$ fragments, from which a $491 \mathrm{bp}$ amplicon was generated in the second PCR (primer pair: ABM fwd and ABM rev). The entire cDNA insert was subcloned into pUC-hygMT via the flanking XbaI sites. For the full-length constructs, the respective $\alpha 7$ cDNA inserts in the pCR2.1 vector were cut with BssHII, blunted, subsequently cut with $\mathrm{XbaI}$ and ligated into the linearized pIRESneo3 vector (ClonTech, Mountain View, CA, USA).

\subsection{Generation of Stably Transfected HT1080 Cells}

In a 24-well-plate, $4 \times 10^{3} /$ well HT1080 cells were transfected with $1 \mu \mathrm{g}$ of SspI-linearized pIRESneo3 constructs encoding full-length $\alpha 7$-cDNAs in 200 $\mu$ l DMEM with $6 \mu \mathrm{L}$ FuGene6 (Promega, Madison, WI, USA), for $30 \mathrm{~min}$. After $8 \mathrm{~h}$, the supernatant was replaced by DMEM $+10 \% \mathrm{FCS}$. Selection started after $48 \mathrm{~h}$, and stable transfectants were cultivated with $400 \mu \mathrm{g} / \mathrm{mL}$ geneticine (Gibco). 


\subsection{Reverse Transcription and Real-Time PCR}

RNAs of transfected HT1080 cells were extracted with RNeasy Mini Kit (Qiagen, Hilden, Germany), transcribed via QuantiTect Reverse Transcription Kit (Qiagen) and analyzed for the amount of ITGA7-encoding cDNA by qPCR with RotorGene SYBR Green PCR Kit in the RotorGene Cycler (both Qiagen). The following primers were used: ITGA7-fw, 5'-TTGCTGTTAGCCACGATCAG-3' and ITGA7-rev: 5'-ATGAAGACATGAGCCCGAAC-3'. Signals were evaluated according to the $\Delta \Delta$ Ct-method [34] and normalized to the glyceraldehyde 3-phosphate dehydrogenase (GAPDH) signal. RNA from non-transfected (naïve) HT1080 cells served as negative control.

\subsection{Flow Cytometry}

Naïve and transfected HT1080 cells were harvested and fixed with ice-cold 70\% ethanol. They were incubated with blocking buffer (1\% BSA/1\% horse serum in PBS, pH 7.4, containing $1 \mathrm{mM}$ $\mathrm{MgCl}_{2}$ and $2 \mu \mathrm{g} / \mathrm{mL}$ aprotinin), and subsequently for $1.5 \mathrm{~h}$ with $1 \mu \mathrm{g} / \mathrm{mL}$ of either mouse anti- $\alpha 7$ antibody (Clone 3C12, Miltenyi, Bergisch Gladbach, Germany) or rat anti- $\alpha 7$ antibody mAb 3518 (Clone \#334908, R\&D, Minneapolis, MN, USA), or an isotype control antibody (mouse or rat IgG, Sigma Aldrich, Deisenhofen, Germany) in the same buffer. After washing and $1 \mathrm{~h}$ incubation with $1 \mu \mathrm{g} / \mathrm{mL}$ phycoerythrin-conjugated secondary antibody in blocking buffer, cells were analyzed in a CyFlow-cytometer with FloMax evaluation software (Sysmex Partec, Münster, Germany).

To quantify the portion of active vs. inactive conformation of $\beta 1$ integrin, non-fixed HT1080 cells were flow cytometrically analyzed after co-staining with biotinylated rat mAb 9EG7 and mouse mAb MEM-101A (Thermo Fisher Scientific, Waltham, MA, USA) in FACSCelesta (BD Biosciences, San Jose, CA, USA) with the FlowJo V10 software (BD Biosciences). The portion of active integrin $\beta 1$ was calculated as a ratio of fluorescence signals for each 9EG7- and MEM-101A-stained cell.

\subsection{Immunofluorescence Staining of Transfected HT1080 Cells}

HT1080 cells were seeded on 8-well chamber glass slides (ibidi, Martinsried, Germany), coated with either $10 \mu \mathrm{g} / \mathrm{mL}$ laminin-111 (a gift of Dr. R. Timpl, MPI Martinsried, Germany) or rat-tail collagen I (Gibco), and incubated at $37{ }^{\circ} \mathrm{C}$ and $5 \% \mathrm{CO}_{2}$ for $1 \mathrm{~h}$. After washing with PBS, fixation with $4 \%$ formaldehyde for $10 \mathrm{~min}$, blocking with blocking buffer ( $\%$ horse serum in PBS) and permeabilization with $0.2 \%$ triton $X-100$, cells were stained with a mouse anti-integrin $\alpha 7$ antibody, Clone 3C12 (1:100) in blocking buffer, at $4{ }^{\circ} \mathrm{C}$, overnight. After being washed, cells were incubated with a secondary Alexa 488-conjugated anti-mouse IgG- antibody (1:1000) (Gibco). F-actin and nuclei were stained with Alexa 568-conjugated phalloidin (1:500) (Gibco) and Hoechst dye (1:1000), respectively, for $1 \mathrm{~h}$ and $2 \mathrm{~min}$. After mounting with mounting medium (Dako, Hamburg, Germany) images of specimens were taken with a confocal microscope LSM800 with an oil immersion 40x objective (Zeiss, Oberkochen, Germany).

\subsection{Transduction of LifeAct GFP into HT1080 Cells and Life Cell Imaging}

The lentiviral pLenti-LifeAct-GFP construct (a kind gift from Dr. S. Huveneers, AMC, Amsterdam, Netherlands) was packaged into lentivirus in HEK-293T cells, using second-generation lentiviral packaging plasmids, pMDG.2 and psPAX2 (both are kind gifts from Dr. D. Trono, Addgene plasmids \#12259 and \#12260), with GeneJammer transfection reagents (Agilent, Waldbronn, Germany). Lentivirus containing supernatant was harvested $72 \mathrm{~h}$ after transfection, concentrated with Lenti- $\mathrm{X}$ concentrator (Clontech, Saint-Germain-en-Laye, France) and used to transduce HT1080 cells with $10 \mu \mathrm{g} / \mathrm{mL}$ polybrene. Cells were selected with $1 \mu \mathrm{g} / \mathrm{mL}$ puromycin (Toku-E, Sint-Denijs-Westrem, Belgium). After $72 \mathrm{~h}$, cells were seeded to 8 -well plastic $\mu$-slide (ibidi) coated with laminin- 111 or collagen I (each at $10 \mu \mathrm{g} / \mathrm{mL}$ ) and incubated at $37^{\circ} \mathrm{C}$ and $5 \% \mathrm{CO}_{2}$ for $1 \mathrm{~h}$. Adhesion and spreading were recorded with video confocal microscopy in a LSM800, at $37^{\circ} \mathrm{C}$, with $10 \times$ and $40 \times$ immersion oil objectives, with one z-stack picture/min for $10 \mathrm{~min}$. For each condition, at least 30 cells were imaged. 


\subsection{Production, Purification and Binding Test of Soluble Integrin $\alpha 7 \beta 1$}

Schneider's cell line- 2 cells were stably co-transfected with pUC-hygMT- $\alpha 7$-Fos (wild type or mutant variants) and pUC-hygMT- $\beta 1$-Jun [11]. Transfected cells were selected with hygromycin B (Merck, Darmstadt, Germany) and subcloned, and their supernatants were tested in sandwich-ELISA with mAB13 (Becton-Dickenson, Franklin Lakes, USA) and a rabbit anti-integrin $\beta 1$-antiserum [12], as capturing and detecting antibodies, respectively. A single cell clone was expanded, and cell cultures for production were upscaled to $6 \mathrm{~L}$ in a Labfors 5 pilot scale bioreactor (Infors, Bottmingen, Switzerland). Culture conditions were $26^{\circ} \mathrm{C}, \mathrm{pH} 6.2$ and pO2 of $50 \%$. Soluble recombinant integrins were prepared as described previously [12,22]. The binding activity of isolated integrin $\alpha 7 \beta 1$, with or without prior incubation with $100 \mu \mathrm{M} \mathrm{H}_{2} \mathrm{O}_{2}$ (Carl Roth $\mathrm{GmbH}$, Karlsruhe, Germany), was analyzed in a titration-ELISA [22] and evaluated as published previously [35].

\subsection{AFM Measurement of Intermolecular Forces between Soluble Integrin $\alpha 7 \beta 1$ and Laminin-111}

Freshly cleaved mica (V1, diameter $20 \mathrm{~mm}$, Plano GmbH, Germany) were coated with $3 \mu \mathrm{g} / \mathrm{mL}$ laminin-111. Cantilevers (MSCT, Bruker AFM Probes International), with a spring constant of $23 \mathrm{pN} / \mathrm{nm}$, were amino-functionalized with $9 \mathrm{M}$ ethanolamine and treated with acetal-PEG-NHS (obtained from H. Gruber, Institute for Biophysics, University of Linz, Linz, Austria) at $2 \mathrm{mg} / \mathrm{mL}$ in a $6 \%(v / v)$ trimethylamine/chloroform solution. For integrin coupling, cantilever was treated with $100 \mu \mathrm{L}$ $125 \mathrm{ng} / \mathrm{mL}$ integrin solution in HEPES for $1 \mathrm{~h}$, at RT, to which $2 \mu \mathrm{L} 1 \mathrm{M}$ sodium cyanoborohydride was added subsequently. Force spectroscopy was performed with a NanoWizard BioAFM (JPK instruments AG, Berlin, Germany). The integrin-decorated cantilever was pressed to the substratum-bound laminin-111 for $1 \mathrm{~s}$ and retracted with a velocity of $300 \mathrm{~nm} / \mathrm{s}$. Retractions were repeated about 900 times. From every force-distance curve, the rupture force for the ultimate separation of cantilever from substratum was determined, to assure single molecular interactions. Force-distance curves showing unspecific cantilever-mica interactions, rupture distances below $20 \mathrm{~nm}$ or ambiguous last rupture events were rejected from evaluation.

\subsection{Expression and Purification of Recombinant Redoxins}

Transformed ClearColi ${ }^{\circledR}$ BL21(DE3) cells (Lucigen, Middleton, WI, USA) with reduced endotoxicity were induced with $1 \mathrm{mM}$ IPTG to produce His-tagged Trx1. After incubation overnight, at RT, bacteria were lysed with $20 \mathrm{mg}$ lysozyme and DNAseI, and by sonification. From the lysate, Trx1 was purified with immobilized metal affinity chromatography columns (GE Healthcare Life Science, Buckinghamshire, UK), checked for purity by SDS-PAGE and tested to be endotoxin-free with the HEK-Blue ${ }^{\mathrm{TM}}$ LPS Detection Kit2 (Invitrogen). For cell experiments, recombinant proteins were rebuffered into TBS, reduced with $10 \mathrm{mM}$ DTT for $30 \mathrm{~min}$, at RT, desalted with Zeba Spin columns (Thermo Fisher Scientific), spectrometrically quantified and applied at $10 \mu \mathrm{g} / \mathrm{mL}$.

\subsection{Intermediate Trapping of Trx 1 to Integrins}

The trapping Trx1 C35S mutant [36] was expressed and purified as His-Tag fusion protein [37]. It was immobilized and reduced with $10 \mathrm{mM}$ DTT on a His-Trap column, onto which 10-20 mg proteins of HT1080 cell lysate was loaded. Bound Trx1-substrates were eluted with $10 \mathrm{mM}$ DTT and analyzed by immunoblot, with an integrin $\beta 1$ antiserum [11], and by mass spectrometry. For the latter, tryptic fragments of trapped proteins were identified with a QExactive plus mass spectrometer [38]. Sequences were searched with MaxQuant (version 1.6.6.0, Max Planck Institute of Biochemistry) in a Homo sapiens reference proteome set (UniProtKB) supplemented with an entry for mouse integrin $\alpha 7$.

\subsection{Impedance-Based Measurement of Cell Adhesion and Migration}

For adhesion studies, E-plates (ACEA Biosciences, San Diego, CA, USA) were coated with $2 \mu \mathrm{g} / \mathrm{mL}$ laminin-111 in PBS, pH 7.4, overnight. After washing with PBS and blocking with $0.1 \%$ BSA in PBS, 
each well was filled with $50 \mu \mathrm{L}$ Tyrode's solution $(140 \mathrm{mM} \mathrm{NaCl}, 5 \mathrm{mM} \mathrm{KCl}, 0.5 \mathrm{mM} \mathrm{MgCl}, 1.8 \mathrm{mM}$ $\mathrm{CaCl}_{2}, 5 \mathrm{mM}$ HEPES, $5 \mathrm{mM}$ Glucose, $\mathrm{pH}$ adjusted to 7.4 with $\mathrm{NaOH}$ ), with or without additional supplements $\left(\mathrm{GoH} 3, \mathrm{H}_{2} \mathrm{O}_{2}\right)$. The cells were harvested, washed and resuspended at $1 \times 10^{6} \mathrm{~mL}^{-1}$. Then, $50 \mu \mathrm{L}$ thereof was added to each well. For migration assays, the bottom filter face of CIM-plates (ACEA Biosciences) was coated with $2 \mu \mathrm{g} / \mathrm{mL}$ laminin-111 solution in PBS, pH 7.4, overnight. The bottom compartment of the CIM plate was filled with $165 \mu \mathrm{L}$ Tyrode's solution, including $1 \%$ FCS as chemotactic stimulus. Then, $5 \times 10^{4}$ cells/well in Tyrode buffer were added to the top compartment. After that, $10 \mu \mathrm{g} / \mathrm{mL} \operatorname{Tr} x 1$ or $10 \mu \mathrm{M} \mathrm{H}_{2} \mathrm{O}_{2}$ was added to both compartments. The experiments were performed at $37{ }^{\circ} \mathrm{C}$, with $5 \% \mathrm{CO}_{2}$. Cell adhesion and spreading in E-plates and cell migration in CIM-plates were recorded as the change of electric impedance (equivalent to "cell index") by the xCELLigence ${ }^{\circledR}$-system and the RTCA software 1.2 (ACEA Biosciences), at 5 min intervals, and corrected for the background values, to obtain $\Delta$ cell index values. Migration rate was determined as slope of $\Delta$ cell index changes over time. Relative $\Delta \Delta$ cell index values for each time point were obtained from the differences of $\Delta$ cell index values of treated and nontreated samples, which were normalized to the $\Delta$ cell index value of the nontreated sample.

\subsection{Negative Staining and Electron Microscopy of Recombinant Soluble $\alpha 7 \beta 1$ Integrin}

The conformation of integrin molecules was analyzed by negative staining electron microscopy [39]. Integrin samples (typically $25 \mu \mathrm{L}$ ) were treated with $10 \mu \mathrm{M} \mathrm{H}_{2} \mathrm{O}_{2}$ or $10 \mu \mathrm{g} / \mathrm{mL}$ thioredoxin-1, respectively, for $1 \mathrm{~h}$ at $37^{\circ} \mathrm{C}$. Carbon-coated 400 mesh copper grids were rendered hydrophilic by glow discharge at low pressure in air. Then, $5 \mathrm{~mL}$ specimen samples were adsorbed onto the hydrophilic grids for $1 \mathrm{~min}$. After washing with two drops of water, the samples were negatively stained with two drops of $0.75 \%$ uranyl-formate. Specimens were examined, using a Philips/FEI CM 100 electron microscope, operated at an accelerating voltage of $80 \mathrm{kV}$; images were recorded with an OSIS Veleta side-mounted digital slow scan $2 \mathrm{k} \times 2 \mathrm{k}$ CCD camera system, using Digital Micrograph ${ }^{\mathrm{TM}}$ software (version 3.4, Gatan Inc., Pleasamton, CA, USA).

\section{Results}

\subsection{Cysteines of the Integrin $\alpha 7$ Subunit Calf-2 Domain Are Structurally Important}

To mechanistically study the six oxidizable cysteine residues within the integrin $\alpha 7$ subunit [22], we mutated (i) the two cysteines within the hinge region, (ii) the four cysteines within the calf-2 domain and (iii) all six cysteines into alanine residues, thereby obtaining the mutants, $\alpha 7 \mathrm{hi}, \alpha 7 \mathrm{ca} 2$ and $\alpha 7$ hi-ca2, respectively (Figure 1a). After transfection of the human fibrosarcoma HT1080 cells with these full-length integrin-encoding cDNAs (Figure 1a, left column), the highest amount of transcribed mRNA was detected in $\alpha 7$ hi-transfectants, as compared to the low transcription level of $\alpha 7$ wild type $(\alpha 7 \mathrm{wt})$ (Figure 1b). Three independent transfections with $\alpha 7 \mathrm{ca} 2$ and $\alpha 7 \mathrm{hi}$-ca2 constructs (\#1-3 in Figure 1b) yielded transcription of the respective cDNAs, yet none of them resulted in protein expression. Only the $\beta 1$ integrin heterodimers with $\alpha 7 \mathrm{wt}$ and $\alpha 7 \mathrm{hi}$ were detected in the cell lysate (Figure 1c).

Surface expression of $\alpha 7 \beta 1$ integrin wild-type and mutants was quantified by flow cytometry, using two distinct mAbs, clones 3C12 and mAb3518. Only $\alpha 7 \mathrm{wt}$ and $\alpha 7$ hi heterodimers were exposed on the cell surface, but not the $\alpha 7 \mathrm{ca} 2$ - or $\alpha 7$ hi-ca2 subunit (Figure 2, left column). To prove whether the latter two are aberrantly folded and hence retained along the secretory pathway, immunofluorescence microscopy of HT1080 adherent to laminin-111 was performed. Integrin $\beta 1$ heterodimers containing either $\alpha 7$ wt or $\alpha 7$ hi were exposed on the cell surface, but none of the $\alpha 7 \mathrm{ca} 2$ or $\alpha 7 \mathrm{hi}$-ca2 (Figure 2). Permeabilization of cells only slightly, if at all, increased the intracellular staining signal of the $\alpha 7 \mathrm{ca} 2$ and $\alpha 7$ hi-ca2 (Figure 2, second column). These data suggested that the mutant $\alpha 7$ integrins with a cysteine-free calf-2-domain were degraded intracellularly after translation. Therefore, the four cysteine 
residues within the calf- 2 domain have a structural but not a regulatory role and are indispensable for proper folding of $\alpha 7 \beta 1$ integrin.

a

\begin{tabular}{|c|c|c|}
\hline & full length integrin & soluble integrin ectodomain \\
\hline \multirow{2}{*}{ a7wt } & 跑 & in \\
\hline & $\begin{array}{l}\text { propeller thigh HI call-1 calf-2 } \\
\text { heavy chain }\end{array}$ & 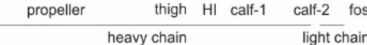 \\
\hline \multirow{2}{*}{ a7hi } & 1 & ing \\
\hline & $\begin{array}{l}\text { propeller thigh HI calf-1 calf-2 TM CP } \\
\text { heavy chain } \\
\text { light chain }\end{array}$ & $\begin{array}{l}\text { propeller thigh HII call-1 call-2 } \\
\text { heavy chain } \\
\text { light chair }\end{array}$ \\
\hline \multirow[t]{2}{*}{ a7ca2 } & M m & m m \\
\hline & $\begin{array}{l}\text { thigh HI calf-1 call-2 } 2 \text { TM CP } \\
\text { heavy chain }\end{array}$ & 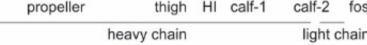 \\
\hline \multirow[t]{3}{*}{ a7hi-ca2 } & n m m & $m$ \\
\hline & thigh $\mathrm{HI}$ calf-1 call-2 $\mathrm{TM} \quad \mathrm{CP}$ & thigh HI call-1 call-2 2 fos \\
\hline & & \\
\hline
\end{tabular}

b

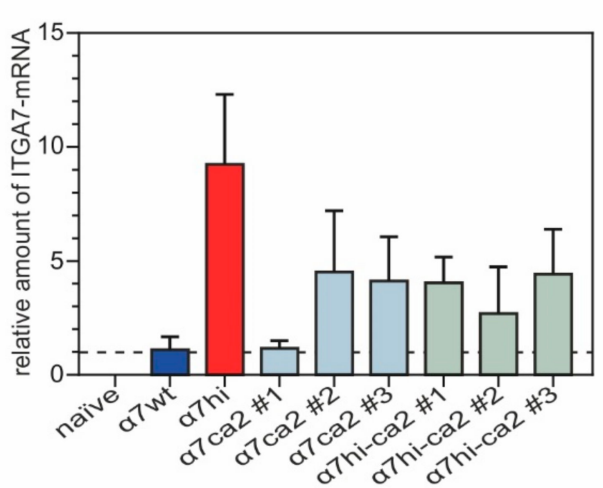

C

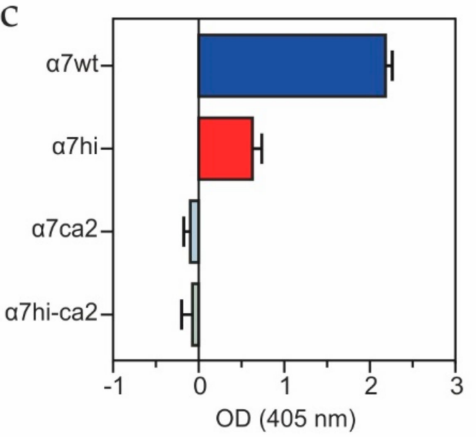

Figure 1. Schematic overview of integrin $\alpha 7$ constructs (a) and quantification of their transcription (b) and translation (c) in transfected HT1080 cells. (a) Redoxmodifiable cysteines of the integrin $\alpha 7$, located within the hinge region (C604, C610) and calf-2 domain (C862, C916, C923, C928) (yellow circles), were replaced by alanine residues (gray diamonds). HI, hinge (knee) domain; TM, transmembrane domain; CP, cytoplasmic domain; fos, heterodimerizing fos-zipper motif. (b) The qRT-PCR analysis of transfected integrin $\alpha 7$ constructs in HT1080 cells. To obtain relative values, the mRNA amounts of the $\alpha 7$ mutants were normalized to the $\alpha 7 \mathrm{wt}$ value (dotted line). Means \pm SD are shown for three independent experiments. Numbers (\#1, \#2 and \#3) for $\alpha 7 \mathrm{ca} 2$ and $\alpha 7 \mathrm{hi}-\mathrm{ca} 2$ indicate three independently transfected cell populations. (c) Sandwich-ELISA of whole HT1080 cell lysates (protein concentration: $1 \mathrm{mg} / \mathrm{mL}$ ) performed with anti-integrin $\alpha 7 \mathrm{mAb} 3 \mathrm{C} 12$ and rabbit anti-integrin $\beta 1$ serum as capturing and detecting antibody.

3.2. The Cysteine Pair within the $\alpha 7$ Integrin Hinge Region Determines the Morphology of Transfected HT1080 Cells

The only expressed mutant, $\alpha 7$ hi, was further analyzed. To this end, HT1080 cells transfected with $\alpha 7 \mathrm{wt}$ - or $\alpha 7$ hi-encoding cDNA constructs were morphologically compared on different ECM substrates, laminin-111 and collagen-I. On laminin-111, a ligand for $\alpha 7 \beta 1$ integrin, HT1080 cells expressing $\alpha 7 \mathrm{wt}$ showed large lamellipodia and spread fully, whereas $\alpha 7$ hi transfectants spread less (Figure 2). In both transfectants, the highest density of surface-exposed integrin $\alpha 7 \beta 1$ was observed close to the cortical actin network at the cell perimeter. On collagen I, an integrin $\alpha 7 \beta 1$-independent substrate, both $\alpha 7 \mathrm{wt}$ and $\alpha 7$ hi transfectants spread indistinguishably from each other, and integrins $\alpha 7$ wt $\beta 1$ and $\alpha 7$ hi $\beta 1$ were found in actin-containing filopodia and membrane ruffles above the cell soma. 


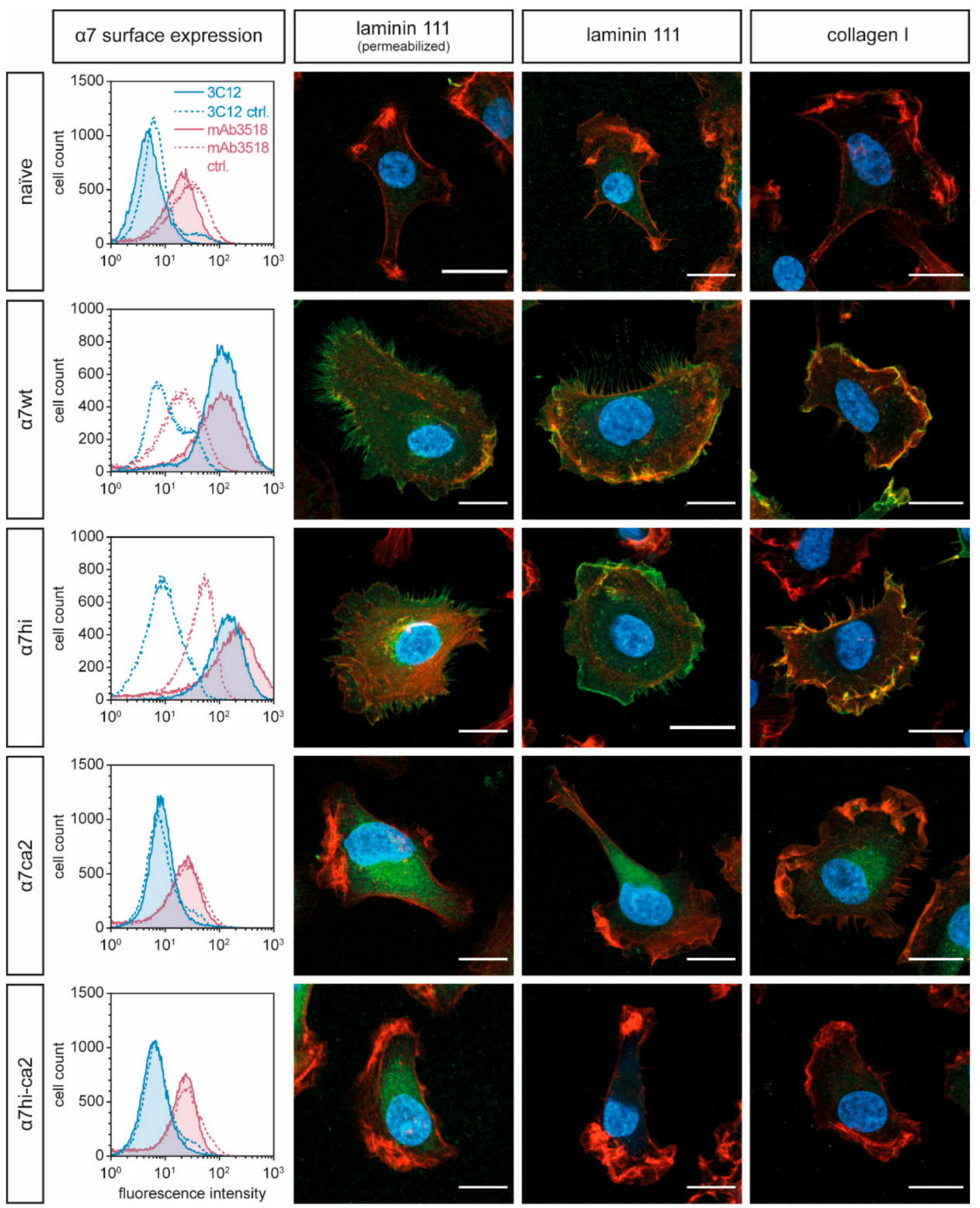

Figure 2. Subunits $\alpha 7 \mathrm{wt}$ and the $\alpha$ hi mutant, but not the $\alpha 7 \mathrm{ca} 2$ and $\alpha 7 \mathrm{hi}$-ca 2 mutants, are expressed as heterodimeric integrin on the surface of transfected HT1080 cells and induce morphological changes of cells after adhesion to laminin-111 and collagen-I. First column: surface exposure of integrin $\alpha 7 \beta 1$ wild type and mutants on transfected HT1080 cells was quantified by flow cytometry independently with two monoclonal antibodies, 3C12 and mAb3518 (clone \#334908). Second to fourth columns: immunofluorescence of adherent transfectants on laminin-111 and collagen-I, either with (second column) or without (third and fourth column) permeabilization, and stained with an anti-integrin $\alpha 7$ antibody $3 \mathrm{C} 12$ (green), with phalloidin (red) and Hoechst dye (blue). Scale bars $=20 \mu \mathrm{m}$. Representative pictures of at least two independent staining experiments with at least 10 cells per condition are shown.

Next, we compared LifeAct-GFP-transfected HT1080 cells bearing $\alpha 7 \mathrm{wt}$ and $\alpha 7$ hi in live-cell imaging, thereby preventing fixation artefacts (Figure 3). On collagen-I, HT1080 cells spread fully and formed lamellipodia and a fringe of filopodia, irrespective of the $\alpha 7$ subunit. In contrast, on laminin-111, only HT1080 cells expressing integrin $\alpha 7 \mathrm{wt}$ developed lamellipodia decorated with numerous filopodia, whereas the $\alpha 7$ hi-transfected cells formed bleb-like cell membrane protrusions. Due to their fragility, these blebs were not detected in cells after fixation and mounting underneath a cover slip (Figure 2). Moreover, non-transfected HT1080 cells formed such blebs, albeit of smaller size 
(Figure 3). These different cell protrusions were likely caused by different adhesion strengths of two $\alpha 7 \beta 1$ integrin forms.

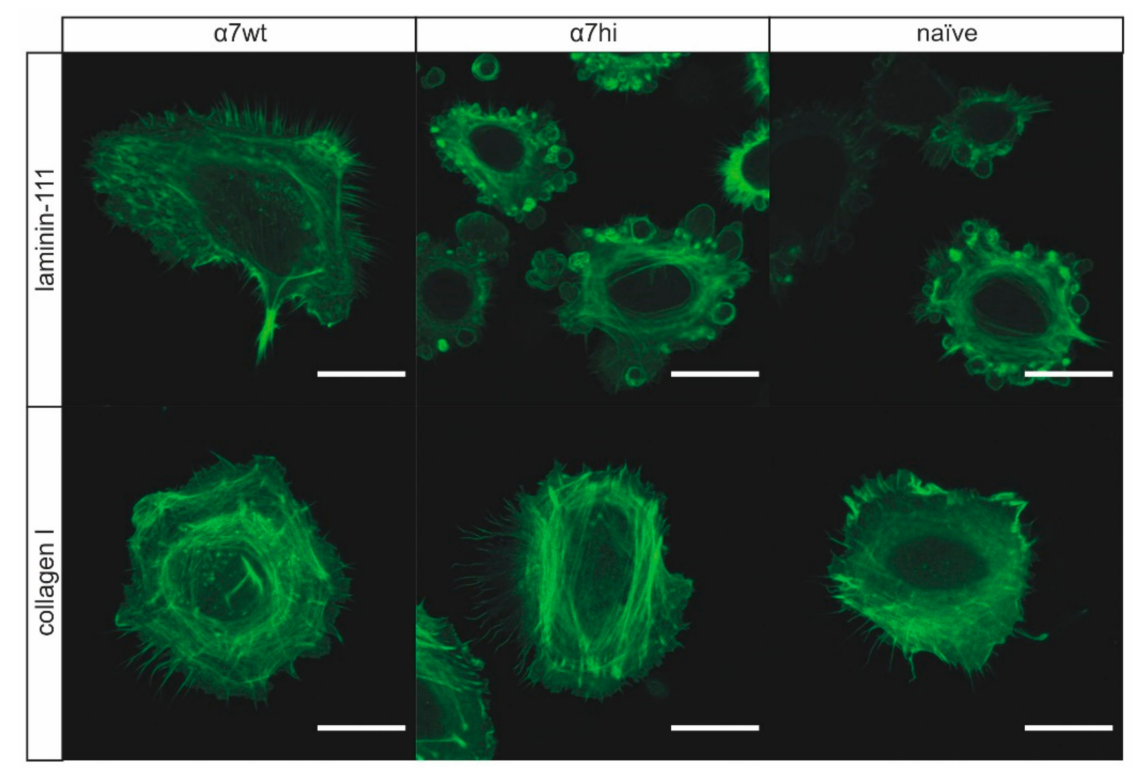

Figure 3. Cell morphology of HT1080 cells expressing $\alpha 7 \mathrm{wt}$ and $\alpha$ hi in life cell microscopy. Integrin $\alpha 7 \mathrm{hi}$, but not $\alpha 7 \mathrm{wt}$, induces bleb-like membrane protrusions in transfected HT1080 cells when plated on laminin-111, but not on collagen I. LifeAct-GFP-transduced HT1080 cells were monitored by life cell microscopy on $\mu$-slides coated with laminin- 111 or rat tail collagen I (ColI). Images were taken with confocal microscopy with $40 \times$ oil objective at $37^{\circ} \mathrm{C}$. Scale bar $=20 \mu \mathrm{m}$. Maximum projection of z-stacks was done with Fiji. Representative images from at least 30 cells for each condition are shown.

\section{3. $\alpha$ 7hi Supports Cell Migration Less Than Integrin $\alpha 7 w t$, Despite a Similar Adhesion Reaction}

Adhesion and migration of $\alpha 7 \mathrm{wt}$ and $\alpha 7 \mathrm{hi}$ transfectants to laminin-111 were assessed by impedance-based measurements in real time. Since HT1080 cells also expressed integrin $\alpha 6 \beta 1$, another receptor for laminin-111, we used the integrin $\alpha 6$-blocking antibody GoH3, to study the role of $\alpha 7 \beta 1$ exclusively. The adhesion of non-transfected HT1080 cells was abolished almost completely, indicating that $\alpha 6 \beta 1$ integrin is the predominant adhesion receptor for laminin-111 on non-transfected HT1080 cells (Figure 4a). Only for the naïve HT1080 cells, the maximum $\Delta$ cell index (Figure 4b) and the maximum slope (Figure 4c) showed significant differences upon $\mathrm{GoH} 3$ treatment. In contrast, irrespective of GoH3, cells transfected with $\alpha 7 \mathrm{wt}$ or $\alpha 7 \mathrm{hi}$ adhered with similar kinetics (Figure 4a) and reached similar maximum adhesion signals (Figure $4 \mathrm{~b}$ ). This indicated that integrin $\alpha 7 \beta 1$ had become the principal adhesion receptor for laminin-111 in transfected cells. Despite their different morphologies (Figure 3), both transfectants similarly adhered with higher adhesion signals than naive HT1080 cells (Figure 4b). The time-dependent increase of impedance values, measured as the maximum slope of the adhesion kinetics in the initial phase, was significantly lower for $\alpha 7 \mathrm{hi}$ - than $\alpha 7 \mathrm{wt}$-transfected cells, presumably due to the less intense cell contacts with the laminin-111-coated electrodes via the bleb-like cell protrusions than via lamellipodia (Figure 4c).

In contrast to adhesion, HT1080 cells expressing integrin $\alpha 7 \mathrm{hi}$ migrated toward laminin-111 significantly slower than the $\alpha 7 \mathrm{wt}$-transfected cells, and even slower than the non-transfected controls, irrespective of the presence of GoH3 (Figure 4d,e). The irrelevance of GoH3 demonstrated that, also for migration toward laminin-111, integrin $\alpha 7 \beta 1$ plays the principal role in transfected cells. Moreover, the lack of the cysteine pair within the $\alpha 7$ hinge decreased cell migration, but not adhesion, to laminin- 111 . 
a

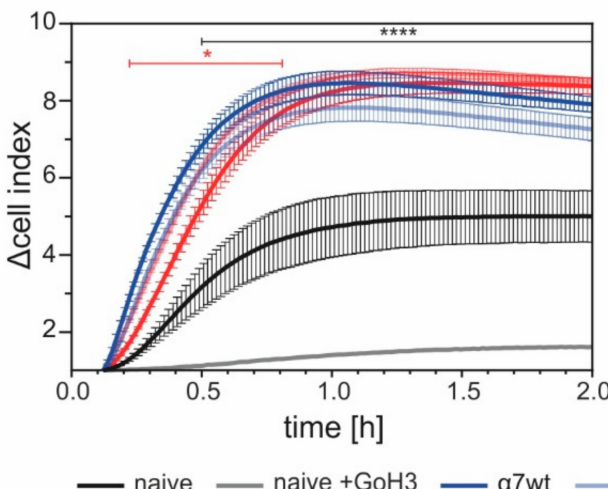

naive naive $+\mathrm{GoH} 3$

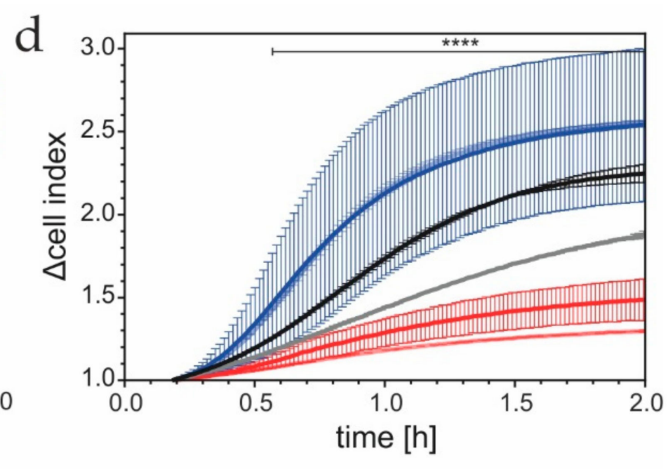

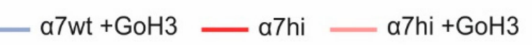
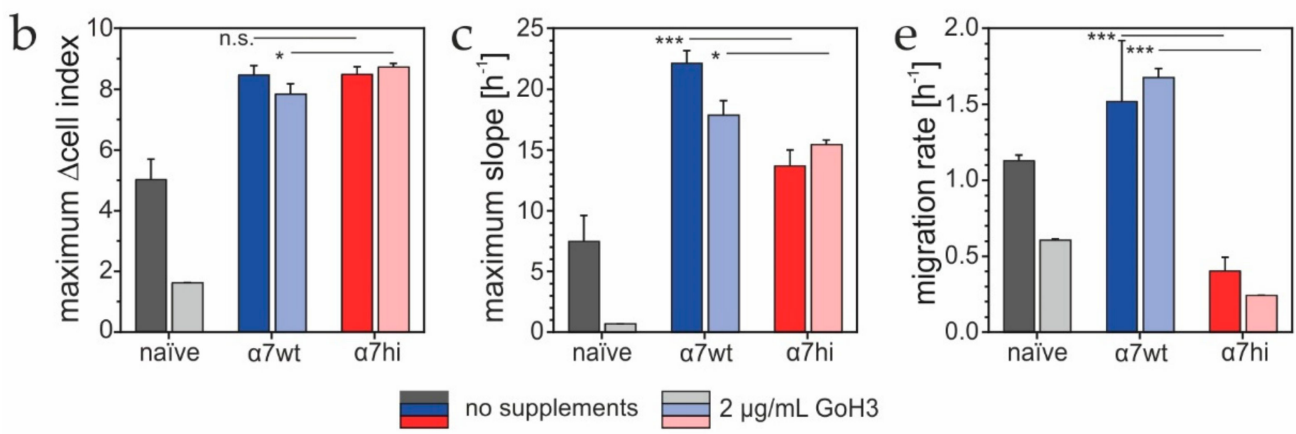

Figure 4. Adhesion and migration of HT1080 cells expressing integrin $\alpha 7 \mathrm{wt}$ and $\alpha 7 \mathrm{hi}$. (a) Adhesion to laminin-111 of naïve and transfected HT1080 cells in an E-plate of the xCELLigence DP device. Cells expressing $\alpha 7 \mathrm{wt}$ or $\alpha 7 \mathrm{hi}$ adhered faster and with a higher saturation signal than the naïve HT1080 cells. Adhesion via $\alpha 6 \beta 1$ integrin was challenged by adding the antibody GoH3. (b) Maximum adhesion signals and (c) maximum slope, indicating the maximum adhesion rate, were compared for at least three independent experiments. Means \pm SD are shown. (d) Haptotactic migration toward laminin-111 of HT1080 cells was recorded in a CIM plate of the xCELLigence DP device. Cells expressing $\alpha$ 7hi moved much slower than $\alpha 7 \mathrm{wt}$ transfectants and naïve cells. (e) The migration rates were determined as change of $\Delta$ cell index values over time, between 30 and $60 \mathrm{~min}$. Experiments were performed in Tyrode's solution. Means \pm SD of a quadruplet determination of one out of three experiments are shown. The data in (a) and (d) were compared for the effect of GoH3 by two-way-ANOVA with multiple comparison correction via the Holm-Sidak method. Time periods with significant differences are marked in the corresponding color of the cells. As only the naïve HT1080 showed significant changes upon $\mathrm{GoH} 3$ treatment after $1 \mathrm{~h}$, the comparison bars for comparing the GoH3-free vs. GoH3-treated samples are omitted in (b), (c) and (e). In the same plots, comparison bars are only shown for the comparison of $\alpha 7 \mathrm{wt}$ vs. $\alpha 7 \mathrm{hi}$ transfectants and are based on pairwise comparisons with Student's $\mathrm{t}$-test. Significance levels: ${ }^{*} p \leq 0.05 ; * * * . p \leq 0.005 ;{ }^{* * * *}, p \leq 0.001$.

3.4. Oxidation of the Cysteine Pair in the Integrin $\alpha 7$ Hinge Results in $\mathrm{H}_{2} \mathrm{O}_{2}$-Promoted Migration of $\alpha 7 w t$-, but Not of $\alpha 7$ hi-Expressing Cells

To test the hypothesis that the pair of cysteines within the hinge motif can be oxidized and consequently influences $\alpha 7 \beta 1$ integrin and its cell functions, chemohaptotactic migration of $\alpha 7 \mathrm{wt}-$ and $\alpha 7$ hi-transfected HT1080 cells toward laminin-111 was compared in the absence vs. presence of $10 \mu \mathrm{M} \mathrm{H}_{2} \mathrm{O}_{2}$ (Figure 5). To avoid nonspecific decomposition of $\mathrm{H}_{2} \mathrm{O}_{2}$, Tyrode buffer without any redox-relevant components was used. The $\alpha 7 \mathrm{wt}$ transfectants showed higher $\Delta$ cell index values in the migration chamber, in response to $\mathrm{H}_{2} \mathrm{O}_{2}$, than nontreated control cells did (Figure 5a), whereas $\alpha 7 h i$ transfectants were not stimulated by $\mathrm{H}_{2} \mathrm{O}_{2}$ (Figure $5 \mathrm{~b}$ ). Thus, the migration rates, which were already significantly higher for $\alpha 7 \mathrm{wt}$ than for $\alpha 7 \mathrm{hi}$ transfectants in the absence of $\mathrm{H}_{2} \mathrm{O}_{2}$, changed differently in its presence (Figure $5 \mathrm{c}$ ). These $\mathrm{H}_{2} \mathrm{O}_{2}$-induced differences became even clearer when 
they were normalized to the nontreated sample (Figure $5 \mathrm{~d}$ ). These relative $\Delta \Delta$ cell index values of $\alpha 7$ hi-transfected cells did not significantly differ from zero over time, showing that these cells did not respond to $\mathrm{H}_{2} \mathrm{O}_{2}$, whereas they rose significantly for $\alpha 7 \mathrm{wt}$ transfectants and persisted over at least two hours (Figure $5 \mathrm{~d}$ ). These data proved that the oxidation of the cysteine pair in the $\alpha 7$ hinge promoted $\alpha 7 \beta 1$ integrin-mediated cell migration.
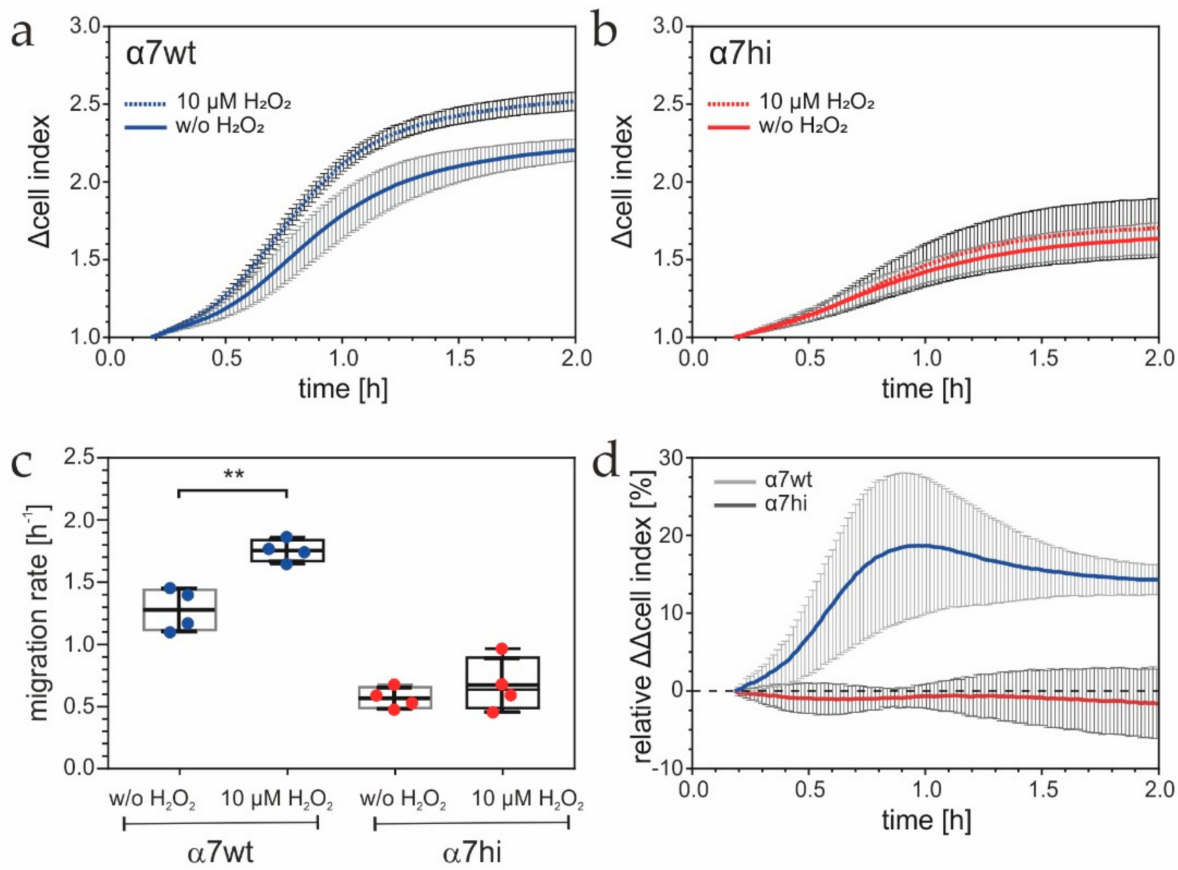

Figure 5. Effect of $\mathrm{H}_{2} \mathrm{O}_{2}$ on integrin $\alpha 7$-dependent migration. Migration on laminin-111 of HT1080 cells expressing integrin $\alpha 7$ wt (a) or $\alpha 7$ hi (b) was monitored on CIM-plates in an XCELLigence DP device, in the absence and presence of $10 \mu \mathrm{M} \mathrm{H}_{2} \mathrm{O}_{2}$. The experiments were carried out in Tyrode's solution and in the presence of $2 \mu \mathrm{g} / \mathrm{mL} \mathrm{GoH} 3$. Means $\pm \mathrm{SD}$. of $\Delta$ cell index values, measured in 5 min intervals, from at least four independent measurements are shown. The Holm-Sidak method revealed a significant difference $(p<0.05)$ for $\alpha 7 \mathrm{wt}-$, but not $\alpha 7$ hi-transfectants, after the first $60 \mathrm{~min}$ of $\mathrm{H}_{2} \mathrm{O}_{2}$ treatment. (c) The average migration rates between 30 and $60 \mathrm{~min}$ after migration start are shown from one of three experiments with quadruplet determination with means \pm SD. Significance level: ${ }^{* *} p \leq 0.01$. (d) Relative $\Delta \Delta$ cell index values were calculated at each time point for HT1080 cells expressing $\alpha 7 \mathrm{wt}$ or $\alpha 7$ hi to compare $\mathrm{H}_{2} \mathrm{O}_{2}$-treated and nontreated samples. Means $\pm \mathrm{SD}$ are shown ( $n=4$ for $\alpha 7 \mathrm{wt}$ and $n=6$ for $\alpha 7 \mathrm{hi}$ ).

\subsection{The Wild-Type $\alpha 7 \beta 1$ Integrin Occurs in a High Activity-Conformation on the Cell Surface at a Higher Frequency Than the $\alpha$ 7hi-Mutant}

We hypothesized that the molecular basis of increased cell migration under oxidizing conditions correlates with an activation and a conformational change of the integrin ectodomain. As the epitope of the mAb 9EG7 within the integrin $\beta 1$ subunit is accessible only in the extended conformation, we employed this antibody to assess the portion of extended integrin conformation within the entire cell surface population of $\beta 1$ integrins. The latter was determined with the anti-integrin $\beta 1$ antibody MEM-101A that recognizes its epitope conformation independently. Being antibodies from different species, 9EG7 and MEM-101A were simultaneously used in flow cytometry (Figure 6a). As positive control, the $\beta 1$ integrin-activating antibody, 12G10, revealed the total fraction of activatable $\beta 1$ integrins (Figure 6b). The flow cytometric MEM-101A signal showed that the $\beta 1$ integrin expression in HT1080 cells transfected with the $\alpha 7 \mathrm{hi}$ construct was equally high as in non-transfected cells. Only the $\alpha 7 \mathrm{wt}$-transfectants exposed less $\beta 1$ integrin on their surface (Figure 6c). Nevertheless, the $\alpha 7 \mathrm{wt}$-transfected cells revealed a significantly higher portion of accessible 9EG7 epitopes than 
the non-transfected cells and $\alpha 7$ hi transfectants (Figure $6 \mathrm{~d}$ ). The little, yet significantly increased portion of 9EG7-accessible $\beta 1$ integrins is especially striking as this test detected not only the extended conformation of active $\alpha 7 \beta 1$ integrin, but of all $\beta 1$ integrins. Therefore, we concluded, that a higher portion of the wild type $\alpha 7 \beta 1$ integrin molecules took the extended conformation and likely possess higher ligand binding activity as compared to the $\alpha 7$ hi $\beta 1$ integrin molecules, which remained in the less-active bent conformation on the cell surface.

a

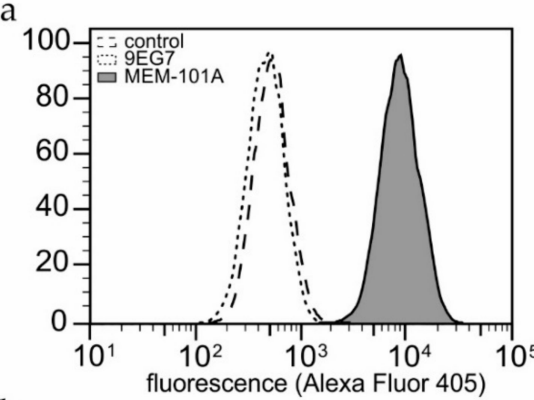

b

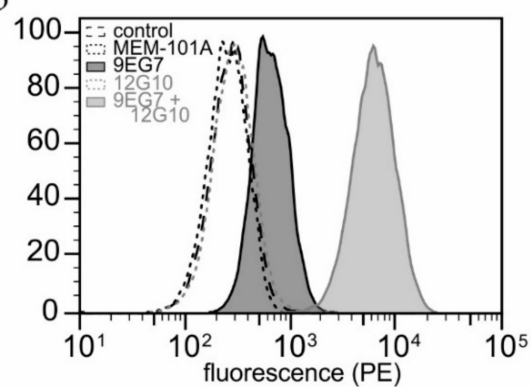

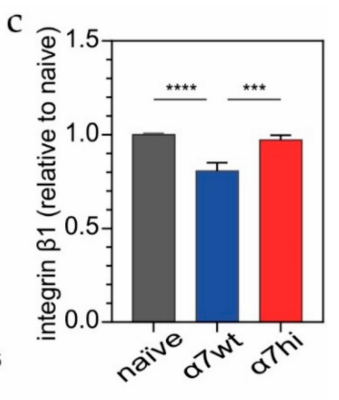

$\mathrm{d}$

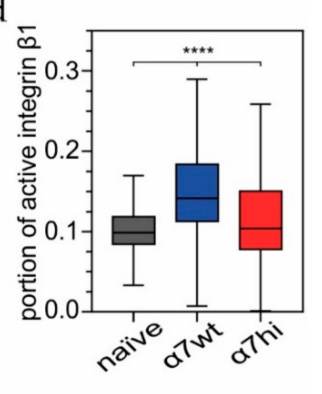

Figure 6. Surface-exposed $\alpha 7 \beta 1$ integrin containing the $\alpha 7 \mathrm{wt}$, but not the $\alpha 7$ hi mutant, preferentially takes the active/extended conformation with an accessible 9EG7 epitope. (a,b) Representative flow cytometric histograms, such as the ones shown here for $\alpha 7 \mathrm{wt}$ transfected HT1080 cells, reveal (a) all $\beta 1$ integrin heterodimers, irrespective of their conformational state, after staining with anti- $\beta 1$ mAb MEM-101A and Alexa Fluor 405-conjugated secondary antibodies. No cross reaction was observed for 9EG7 as primary antibody. (b) Integrin $\beta 1$ molecules in an extended conformation stained with biotinylated 9EG7 and secondarily with phycoerythrin (PE)-conjugated NeutrAvidin. No cross reaction was detected for MEM-101A or 12G10 as primary antibodies. To prove 9EG7 functionality, $\beta 1$ activating antibody $12 \mathrm{G} 10$ was added along with 9EG7, representing the maximum signal reachable with 9EG7. (c) All surface-exposed $\beta 1$-integrins were detected with MEM-101A antibody in a conformation-independent manner. The quantity of $\beta 1$-integrins was lower in HT1080 cells transfected with the $\alpha 7 \mathrm{wt}$ construct. (d) 9EG7 detected the portion of active conformation of integrin $\beta 1$ relative to the maximum reachable signal in presence of $12 \mathrm{G} 10$. Box plots indicate medians, 25th and 75th percentile, and Tukey whiskers. In total, 12,720, 9117 and 8349 events were evaluated for naïve, $\alpha 7 \mathrm{wt}$ and $\alpha 7 \mathrm{hi}$, respectively. ANOVA with Tukey's multiple-comparisons test was performed. Significance levels are indicated by asterisks $\left.{ }^{* * *} p \leq 0.005 ;{ }^{* * * *} p \leq 0.001\right)$.

3.6. Oxidation of the Cysteine Pair Within the Hinge Region of Integrin $\alpha 7 \beta 1$ Increases Binding Activity and Force to Laminin-111

To analyze the molecular mechanism of the thiol-based redox regulation within the integrin $\alpha 7$ hinge, we recombinantly produced the corresponding soluble $\alpha 7 \beta 1$ integrin ectodomains (Figure 1 , right column). Both $\alpha 7 \mathrm{wt} \beta 1$ and $\alpha 7 \mathrm{hi} \beta 1$ integrins interacted with immobilized laminin-111 in the protein-chemical binding ELISA (Figure 7a). However, the binding signals of soluble $\alpha 7 \mathrm{wt} \beta 1$ were consistently higher than the ones of $\alpha 7 h i \beta 1$, presumably in correlation with the more active conformation. Moreover, $\alpha 7$ hi $\beta 1$ had a lower affinity to laminin- 111 than the wild-type form. When laminin-111 binding was challenged with $100 \mu \mathrm{M} \mathrm{H}_{2} \mathrm{O}_{2}$ (Figure 7a), the dissociation constant of $\alpha 7 \mathrm{wt} \beta 1$, but not of $\alpha$ 7hi $\beta 1$, increased slightly. More strikingly, the saturation binding signals of $\alpha 7 \mathrm{wt} \beta 1$, but 
not of $\alpha 7$ hi $\beta 1$, rose remarkably by more than $72 \%$ upon $\mathrm{H}_{2} \mathrm{O}_{2}$ treatment, indicating an increase of integrin molecules with the higher activity conformation. Thus, the cysteine pair within the integrin $\alpha 7$ hinge is sufficient to redox-regulate ligand-binding activity. Moreover, the dramatic changes of the saturation-binding signals of $\alpha 7 \mathrm{wt} \beta 1$ integrin, in combination with the subtle change of $\mathrm{K}_{\mathrm{D}}$-values upon $\mathrm{H}_{2} \mathrm{O}_{2}$ treatment, suggested that the oxidation of the cysteine pair within the $\alpha 7$ hinge rather acts allosterically instead of affecting the laminin binding site.
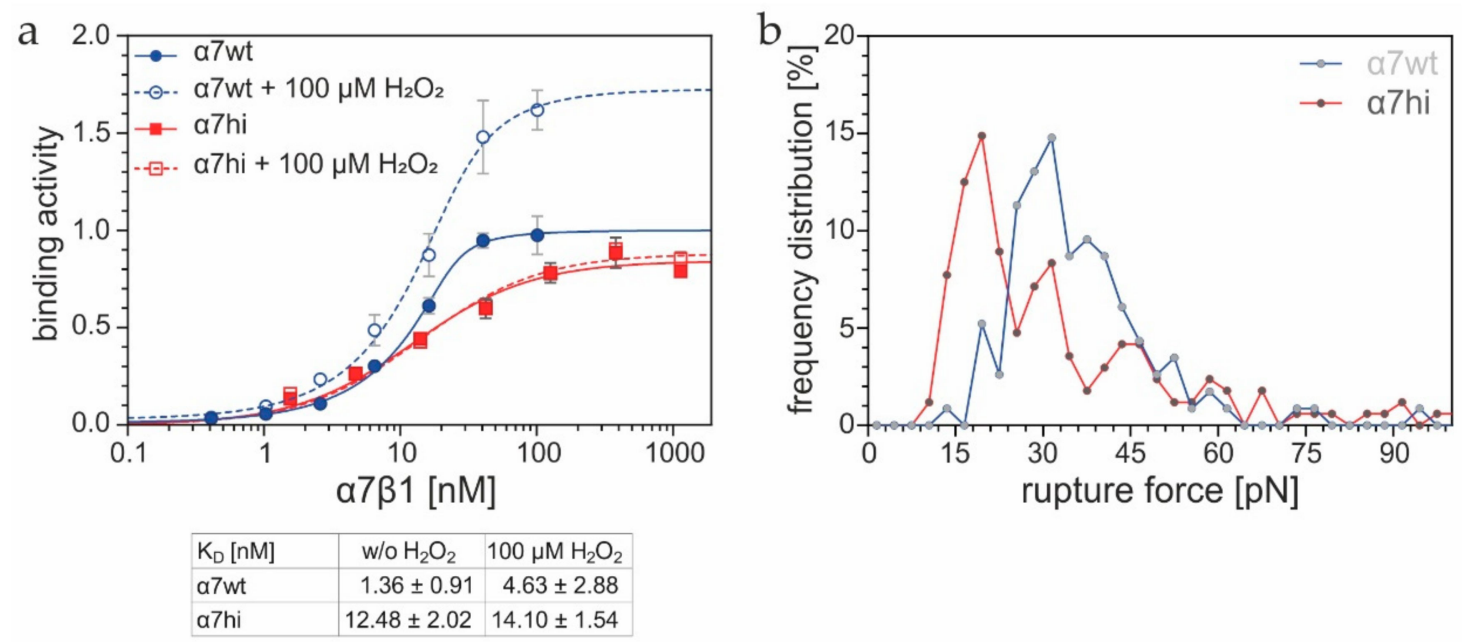

Figure 7. Ligand-binding activity and binding force of $\alpha 7$ integrins toward laminin-111. (a) Soluble integrins, $\alpha 7 \mathrm{wt} \beta 1$ and $\alpha 7 \mathrm{hi} \beta 1$, pretreated with or without $100 \mu \mathrm{M} \mathrm{H}_{2} \mathrm{O}_{2}$, were added to immobilized laminin-111. Means $( \pm \mathrm{SEM})$ of triplicates of a representative experiment are shown. At least six titration curves for each condition were fitted according to [35], to obtain $K_{D}$ values. (b) AFM-based force measurements on single molecule interactions between integrins, $\alpha 7 \mathrm{wt} \beta 1$ and $\alpha 7 \mathrm{hi} \beta 1$, and laminin- 111 . After the cantilever with immobilized integrin was approached to the laminin-111 coated surface, it was retracted with a velocity of $300 \mathrm{~nm} / \mathrm{s}$. Force curves for $\alpha 7 \mathrm{wt}$ and $\alpha 7 \mathrm{hi}$ were measured two times, with three loading rates. Rupture force of the last contact was evaluated for 331 and 168 significant force-distance curves for $\alpha 7 \mathrm{wt}$ and $\alpha 7 \mathrm{hi}$, respectively. For the histogram, the results were binned with a force width of $3 \mathrm{pN}$.

To determine molecular forces, rupture forces were measured upon retraction of the integrin-coated cantilever from a laminin-111-coated surface. In the histogram of these yield forces, both integrins showed several peaks of different heights, potentially representing interactions between one, two and more integrin-ligand pairs (Figure $7 \mathrm{~b}$ ). Consequently, the highest peak at lowest yield force represented the single molecule interactions. It showed a similar frequency for both integrin forms. However, most $\alpha 7 \mathrm{wt} \beta 1$ integrin molecules, when bound to one laminin-111 molecule, withstood forces of about $30 \mathrm{pN}$, whereas the highest portion $\alpha 7$ hi $\beta 1$ integrin molecules released its bound laminin- 111 molecule at lower forces, of about $16 \mathrm{pN}$.

\subsection{The Integrin Ectodomain Is a Substrate for Thioredoxin-1, Which Reduces the Integrin $\alpha 7 w$ Thiol-Switch}

These cellular and molecular findings suggested that the hinge-located pair of cysteines constitutes a thiol-switch that, depending on its redox state, alters the conformation and ligand-binding activity of the integrin. A thiol-switch must be reversible to be part of a redox signaling circuit. Since this putative hinge thiol-switch is located in the integrin ectodomain, it should be accessible to and cleavable by an extracellular reducing agent, such as the oxidoreductase Trx1. To test this hypothesis, $\alpha 7 \mathrm{wt} \beta 1-$ and $\alpha 7$ hi $\beta 1$-bearing HT1080 cells, either without or with prior treatment with $\mathrm{H}_{2} \mathrm{O}_{2}$, were allowed to migrate toward laminin-111, in the presence or absence of reduced Trx1 (Figure 8a). To reveal the effect of reduced $\operatorname{Trx} 1$ on cell migration, the relative $\Delta \Delta$ cell index values were determined for each time point. Three of the four pretreatment conditions, i.e., (i) $\alpha 7 \mathrm{wt}$ without $\mathrm{H}_{2} \mathrm{O}_{2}$ pretreatment, (ii) $\alpha 7 \mathrm{hi}$ 
with $\mathrm{H}_{2} \mathrm{O}_{2}$ pretreatment and (iii) $\alpha 7$ hi without $\mathrm{H}_{2} \mathrm{O}_{2}$ pretreatment, showed a clear Trx1-dependent increase in relative $\Delta \Delta$ cell index values of at least $50 \%$ in the first $5 \mathrm{~h}$ of the experiment (Figure $8 \mathrm{~b}$ ). We hypothesized that this increase is a pleiotropic promigratory effect of Trx 1 on cells that is not related to integrins. In fact, Trx1 dose-dependently supported cell migration on integrin-independent substrates, e.g., poly-L-lysine (Appendix A, Figure A1). In contrast to the three other pretreatment conditions, only in the fourth condition, the $\alpha 7 \mathrm{wt}$ transfectants with $\mathrm{H}_{2} \mathrm{O}_{2}$ pretreatment did not migrate toward laminin-111, in the presence of reduced Trx1 with a similarly proportional increase (Figure 8a). They showed remarkably lower Trx1-dependent relative $\Delta \Delta$ cell index values, which approached zero values (Figure $8 \mathrm{~b}$, purple line). This suggests that reduced Trx1 attenuated the activated integrin $\alpha 7 \mathrm{wt} \beta 1$ with its previously $\mathrm{H}_{2} \mathrm{O}_{2}$-oxidized thiol-switch by reducing it and reverting the integrin into its lower activity conformation. Our data indicate that the hinge-located pair of cysteines constitutes a regulatory thiol-switch, which, as a dithiol, is activated by $\mathrm{H}_{2} \mathrm{O}_{2}$ and, as a disulfide bridge, is attenuated byTrx1, respectively. Neither oxidative nor reductive conditions affected the a7hi mutant.
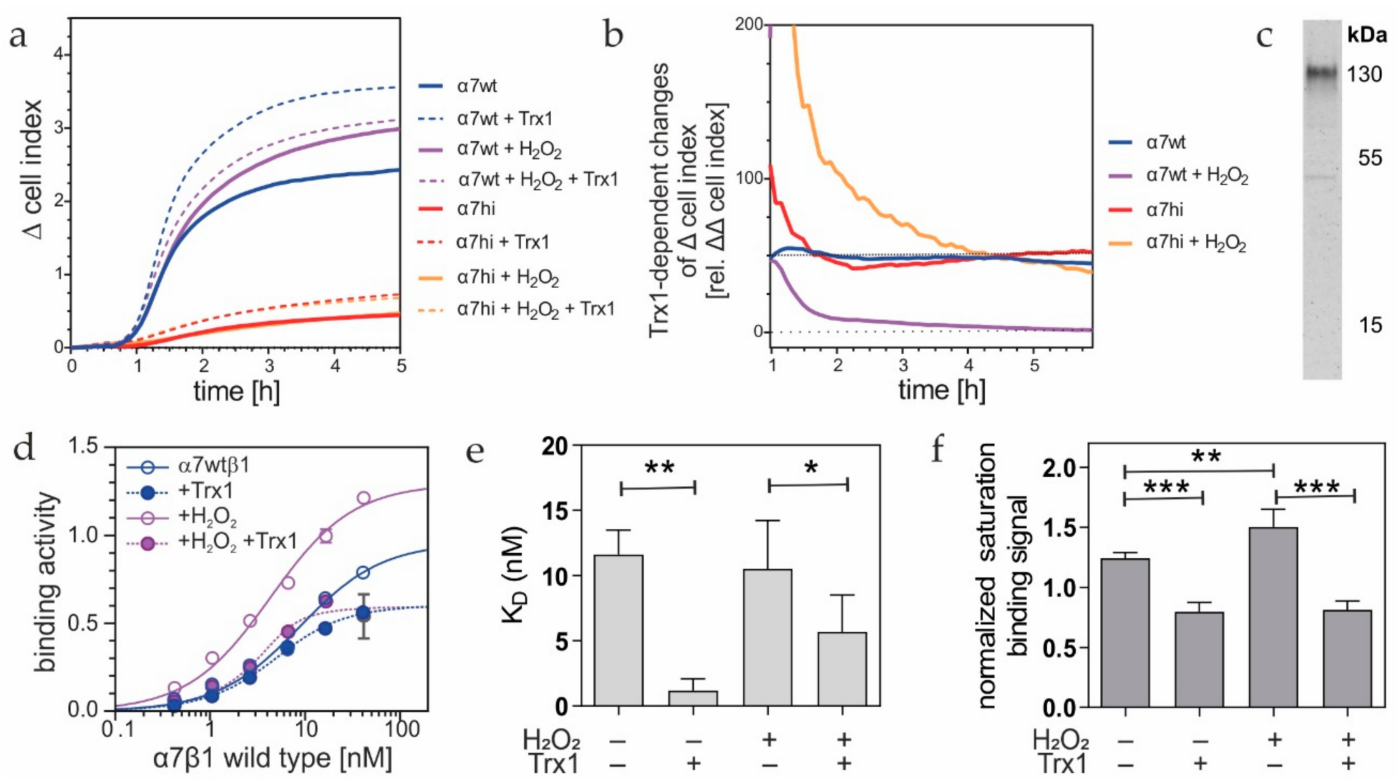

Figure 8. Extracellular thioredoxin-1 (Trx1) reduces cell migration and binding to laminin-111, mediated by $\alpha 7 \mathrm{wt} \beta 1$, but not by $\alpha 7 \mathrm{hi} \beta 1$ integrin. (a) Migration of HT1080 cells toward laminin- 111 . HT1080 cells expressing integrin $\alpha 7 \mathrm{wt}$ (blue and purple lines) or $\alpha 7 \mathrm{hi}$ (red and orange lines) were pretreated without and with $10 \mu \mathrm{M} \mathrm{H}_{2} \mathrm{O}_{2}$ for $30 \mathrm{~min}$ and washed. Migration was monitored on CIM-plates in the $x$ CELLigence DP device, in the absence (full line) and presence (dashed line) of $10 \mu \mathrm{g} / \mathrm{mL}$ reduced Trx1 in Tyrode's solution. Means of triplicate $\Delta$ cell index values from at least three independent measurements are shown. The variation coefficients varied around $10-20 \%$ on average. (b) For every time point, relative $\Delta \Delta$ cell index values were calculated from the data in (a), revealing the Trx1-dependence of the measured values. Means of triplicate values are shown for one out of three representative experiments. (c) Immunoblot detection of $\beta 1$ integrins in the eluate of a Trx1-trap mutant affinity column. The Trx1 trap mutant with its Cys-X-X-Ser active site retained Trx1-bound proteins from a cell lysate of $\alpha 7 \mathrm{wt}$-transfected HT1080 cells. In parallel, the eluate contained inter alia the integrin $\alpha 7$ subunit, as proven by mass spectrometry (Appendix A, Figure A2). (d) Titration of laminin-111 with soluble $\alpha 7 \mathrm{wt} \beta 1$ integrin, pretreated without and with $100 \mu \mathrm{M} \mathrm{H}_{2} \mathrm{O}_{2}$ (blue and purple lines). After removal of $\mathrm{H}_{2} \mathrm{O}_{2}$, binding was tested in the presence (dashed lines) and absence (full line) of $10 \mu \mathrm{g} / \mathrm{mL}$ Trx1, including a subsequent NEM-treatment, to prevent thiol oxidation. One triplicate set of two independent titration experiments are shown. (e) $\mathrm{K}_{\mathrm{D}}$-values, and (f) saturation binding signals of six independent titration curves (as shown in $(\mathrm{d})$ ) were evaluated, and their means \pm SD are shown. Significance levels are indicated by asterisks: ${ }^{*} p \leq 0.05 ;{ }^{* *} p \leq 0.01 ;{ }^{* *} p \leq 0.005$. 
At the molecular level, we aimed to prove a direct interaction of Trx 1 and $\alpha 7 \beta 1$ integrin. The intermediate trapping approach employs a Trx 1 trapping mutant with one mutated cysteine in the active site. It detects substrates that undergo Trx1-catalyzed dithiol-disulfide exchange reactions. This Trx1-trapping mutant was immobilized as a bait on an affinity column. The eluted proteins stained positive for $\beta 1$ integrin in the immunoblot (Figure $8 \mathrm{c}$ ), and mass spectrometric analysis identified the integrin $\alpha 7$ subunit among the Trx1-trapped proteins (Appendix A, Figure A2). Hence, Trx1 interacted with $\alpha 7 \beta 1$ integrin, which thus proved to be a potential redox substrate of $\operatorname{Tr} x 1$.

To substantiate this hypothesis further, we recapitulated the Trx1-mediated reduction of $\alpha 7 \mathrm{wt} \beta 1$ integrin after $\mathrm{H}_{2} \mathrm{O}_{2}$ oxidation at the molecular level in an in vitro assay. Although prior oxidation of $\alpha 7 \mathrm{wt} \beta 1$ integrin increased the binding signals to laminin-111, both non- $\mathrm{H}_{2} \mathrm{O}_{2}$-treated and $\mathrm{H}_{2} \mathrm{O}_{2}$-oxidized $\alpha 7 \mathrm{wt} \beta 1$ integrin approached similar low binding values in the presence of Trx1 (Figure $8 \mathrm{~d}$ ). Trx1 reduced the $\mathrm{K}_{\mathrm{D}^{-}}$-values of $\alpha 7 \mathrm{wt} \beta 1$ integrin to laminin-111, albeit not by orders of magnitude (Figure 8e). Even more significantly, Trx1 decreased the saturation binding signals (Figure 8f), in line with the lower portion of molecules in the extended conformation of the integrin population.

To prove their conformations at the molecular level, the integrins, $\alpha 7 \mathrm{wt} \beta 1$ and $\alpha 7$ hi $\beta 1$, were visualized by transmission electron microscopy after negative staining (Figure 9a). Only 17.4\% of the $\alpha 7 \mathrm{wt} \beta 1$ integrins took a bent conformation, which, in contrast, was found for $97.1 \%$ of the $\alpha 7 \mathrm{hi} \beta 1$ molecules. Treatment of the latter with neither $\mathrm{H}_{2} \mathrm{O}_{2}$ nor $\operatorname{Tr} x 1$ changed the conformational equilibrium (Figure 9a, right column). In contrast, the percentage of bent conformations within the $\alpha 7 \mathrm{wt} \beta 1$ decreased from $17.4 \%$ to $1.6 \%$ after oxidation with $\mathrm{H}_{2} \mathrm{O}_{2}$, whereas it drastically increased to $96.1 \%$ after Trx treatment (Figure 9a, left column). Moreover, further differentiation of integrin population of the extended conformation [5] revealed that treatment with $\mathrm{H}_{2} \mathrm{O}_{2}$ converted $\alpha 7 \mathrm{wt} \beta 1$ integrin molecules not only into the extended close, but also into the extended open conformation (Figure 9b). Trx1 had a converse effect. In contrast, $\alpha 7$ hi $\beta 1$ integrin did not change their conformation at all and remained in the bent conformation (Figure 9b).

These structural data showed that the hinge-located cysteine pair within integrin $\alpha 7 \beta 1$ forms a thiol-switch, which dominantly governs the conformation of the integrin. It is redox-regulated by extracellular $\mathrm{H}_{2} \mathrm{O}_{2}$ and $\mathrm{Trx} 1$. The former causes formation of a disulfide bridge and conversion of the integrin into the extended open conformation with high ligand-binding activity, whereas the latter conversely reduces the disulfide bridge and converts the integrin in a bent conformation with low ligand-binding activity. This redox-dependent conformational conversion results in redox-dependent migration of $\alpha 7 \beta 1$ integrin-expressing cells toward laminin-111. 

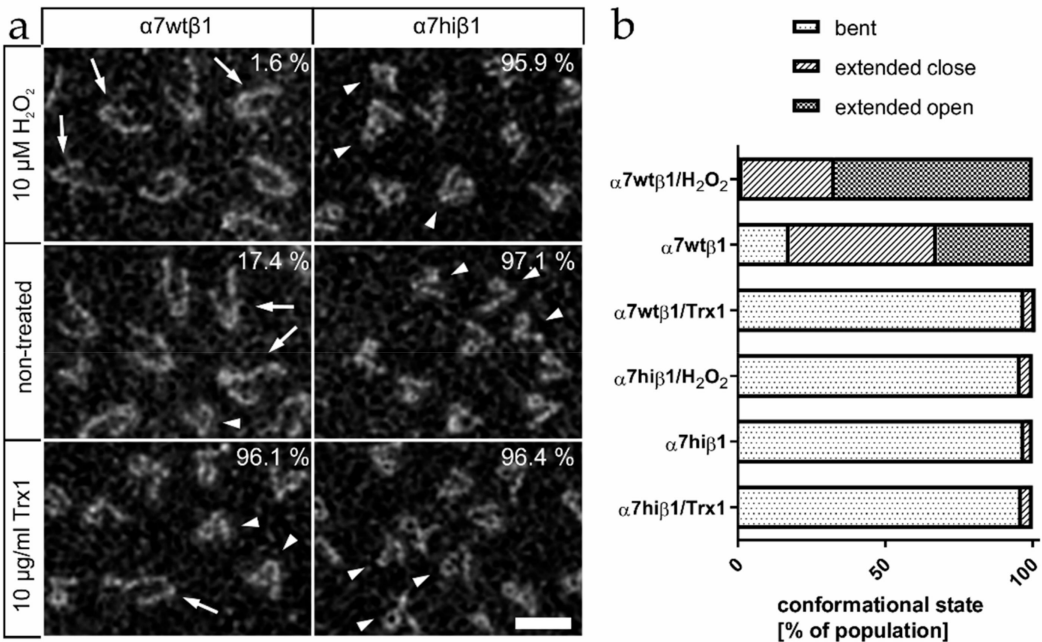

c

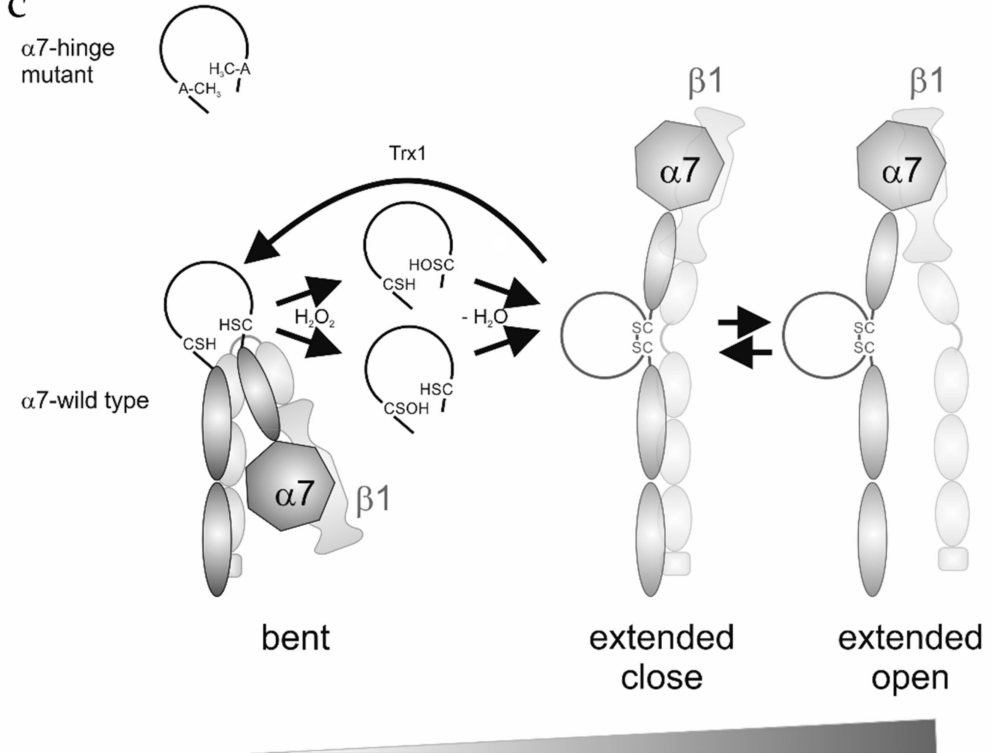

9EG7 epitope accessibility, laminin binding activity and force

Figure 9. Electron microscopy of recombinant soluble $\alpha 7 \beta 1$ integrin after negative staining. (a) The electron micrographs show representative fields of $\alpha 7 \mathrm{wt} \beta 1$ (left column) and $\alpha 7 \mathrm{hi} \beta 1$ (right column) molecules (scale bar: $20 \mathrm{~nm}$ ). The tadpole-like complexes with one or two tails exhibit both bent (arrowheads) and extended (arrows) integrin forms. The percentage of molecules in different conformations was determined from at least 500 molecules under each condition (top row: no additives; middle row: $10 \mu \mathrm{M} \mathrm{H}_{2} \mathrm{O}_{2}$; bottom row: $10 \mu \mathrm{g} / \mathrm{mL}$ Trx1). The percentage of bent conformation is printed in each image. (b) Quantification of conformations of integrin molecules from electromicrographs, such as in (a), including a differentiation of the extended conformation into an extended close and extended open conformation. (c) Scheme of the thiol-switch mediated conformational changes of $\alpha 7 \beta 1$ integrin. The integrin hinge region is indicated as the loop in the central pivot region of the integrin molecule. Rotation around the hinge ensures the conformational equilibrium between bent and extended form. The pair of cysteines within the $\alpha 7$ hinge in the bent conformation is oxidized with $\mathrm{H}_{2} \mathrm{O}_{2}$ to mono-cysteine-sulfenic acid derivatives, which form a disulfide bond. This stabilizes the extended conformations. The disulfide-bonded form of the thiol-switch can be reduced by extracellular Trx1. This is accompanied with transition into the bent conformation. Mutation of both cysteines for alanines (upper left panel) represents the loop structure of the less active $\alpha 7$ hi. The thiol-switch-dependent conformational changes correlate with changes in ligand binding, in 9EG7 epitope recognition and in cell migration. 


\section{Discussion}

Integrins possess numerous cysteine residues within their ectodomains. At least 56 cysteines are located within the integrin $\beta$ subunit, and integrin $\alpha$ chains encompass between 19 and 35 cysteine residues [19,40]. The formation of disulfide bridges is largely conserved among the different integrin $\alpha$ and $\beta$ subunits. However, the controversially reported patterns of some disulfide bridges might not only be due to differences between their crystallographic and protein-chemical mapping [41,42], but also due to different conformations of integrins. Previous observations showed that the patterns of disulfide bonds and free thiol groups of cysteine within their ectodomains may influence ligand binding of integrins [28]. They had been studied for the fibrinogen receptor $\alpha \operatorname{Ilb} \beta 3$, for the collagen-binding integrin $\alpha 2 \beta 1$ on platelets [30,31,43] and for $\beta 2$ integrins on neutrophils [44]. The disulfide bonds can be cleaved by reducing agents or even by photolysis with UV-C light [45]. Data published by us and others also demonstrated that $\mathrm{H}_{2} \mathrm{O}_{2}$, at physiological concentrations of up to $100 \mu \mathrm{M}$ forms disulfide bridges and activates $\beta 1$ integrins, $\alpha 7 \beta 1$ and $\alpha 4 \beta 1$ [22,46]. Beyond those findings, here, we pinpoint one specific thiol-switch (Cys604-C610) and show its dominant role in binding activity and integrin conformation. In this study, we mutated six particular cysteine residues, which we had previously mapped to be oxidizable cysteines [22]. By comparing results from molecular and cellular studies, we not only verified the importance of the eminent cysteine pair, Cys604 and Cys610, within the $\alpha 7$ hinge, but also unraveled that this cysteine pair is fully sufficient to implement a redox-dependent change of conformation and ligand binding activity on $\alpha 7 \beta 1$ integrin. Hence, it is the dominant regulatory thiol-switch. Conspicuously, this cysteine pair is highly conserved in the integrin $\alpha$ subunits, implying the hypothesis that other integrins undergo a similar thiol-based redox regulation via this particular hinge-located thiol-switch.

Several other disulfide bonds within integrin ectodomains are in discussion to fulfill similar redox-regulatory roles, such as cysteine pairs within the $\beta 3$ subunit located within the I-domain [27], within the EGF-domains of the stalk region [24,28-30], or between the PSI- and EGF1-domain as a long-range cysteine bond [31]. Within the integrin $\alpha$ subunits, cysteine bridges within the propeller domain and in the hinge region of integrin subunit $\alpha 4$ were delineated for their reducibility [24-26]. However, the integrin $\alpha 4$ subunit stands apart from other integrins because of its specific proteolytic processing likely within the thigh domain close to the hinge region and because of its easy dissociation into a heavy and light chain [47]. It is noteworthy that simultaneous mutation of all four redox-modifiable cysteine residues within the calf- 2 domain in our study abolished stable expression of the respective $\alpha 7$ subunit due to their structural functions. Other examples of such structurally relevant disulfide bonds within other integrin subunits are of clinical relevance [48].

The biochemical binding tests revealed that replacement of the thiol-switch-forming cysteines for two alanine residues did not entirely abolish the binding affinity of $\alpha 7 \beta 1$ integrin for laminin-111. This is in line with the fact that the putative ligand-binding head domain, which consists of the $\alpha 7$ chain propeller domain and the $\beta 1 \mathrm{I}$-domain, is located in a distance from the hinge region. Hence, modification of the hinge region acts allosterically and the corresponding conformational change explains why the saturation signal, but not the affinity, of the hinge mutant changed remarkably in comparison to the wild type form. Thereafter, and in correlation with our electron microscopy-based conformational studies, the proportion of $\alpha 7 \beta 1$ integrin molecules in the extended open conformation with enhanced ligand binding activity is higher in the population of $\alpha 7 \mathrm{wt}$ than $\alpha 7 \mathrm{hi}$ mutant. This is also in line with the higher flow cytometric signal of the 9EG7 antibody in the cell-bound population of $\alpha 7 \mathrm{wt} \beta 1$ than of $\alpha 7 \mathrm{hi} \beta 1$, as the 9EG7 epitope located within the EGF-domains of the $\beta 1$ subunits is accessible only in the extended conformation of $\beta 1$ integrins [5-7]. Undergoing the common receptor recycling, integrins are taken up by cells especially in an active conformation [49]. This may explain the lower surface expression of $\beta 1$ integrins in $\alpha 7 \mathrm{wt}$ - than in $\alpha 7$ hi-transfectant cells, as detected by the conformation-independent MEM-101A antibody.

The $\alpha 7$ hi $\beta 1$ integrin molecule withstands lower retraction forces than the corresponding wild-type molecule in AFM measurements. In a previous study, we showed that molecular binding forces 
between the $\alpha 7 \beta 1$ wild-type integrin and its ligand invasion comply with a catch-bond model including two barriers $[50,51]$. Although measured at the same low loading rate, the yield forces of wild type and mutant integrin differed in their frequency distributions and minimum yield force. This is likely due to the different percentages of extended vs. bent conformation in the populations of integrin molecules, in line with the weaker interaction of $\alpha 7 \mathrm{hi} \beta 1$ vs. $\alpha 7 \mathrm{wt} \beta 1$ integrin with laminin-111. This lower binding activity of the $\alpha 7 \beta 1$ molecule lacking only the thiol-switch within the $\alpha 7$ hinge region contrasts with the published finding that a mutant of $\alpha 4 \beta 7$ integrin, in which cysteine pairs within the knee regions of both subunits were mutated, showed higher and constitutive activity [24]. This discrepancy might be caused by simultaneous modifications of pivot regions of both subunits or by the unique posttranslational proteolysis and subunit dissociation propensity of the $\alpha 4 \beta 7$ integrin [47].

Our molecular data were complemented with data measured at the cellular level. Expressed by HT1080 cells, the thiol-switch-deficient $\alpha 7 \beta 1$ mutant caused less spreading and induced a different cell morphology on laminin-111, as compared to the wild type form. The bleb-like cell protrusions of the $\alpha 7$ hi transfectants indicate a weak cell adhesion to laminin-111, in accordance with its weaker molecular interaction with its ligand. This also explains the significantly weaker migration of the hinge mutant-transfected cells, as migration depends on repetitive attachment and detachment events. Our data are in agreement with the observation that poor integrin-matrix interactions reinforce an amoeboid migration mode, in which cells move by forming such bleb-like cell protrusions through the activity of their cortical actin network [52,53].

The molecular basis of redox-regulatory proteins can be a thiol-switch which may consist of a pair of cysteines, whose side chains' reversibly change between a dithiol form and a disulfide configuration. The resulting conformational change within the integrin shifts the conformational equilibrium within the integrin population when oxidizing and reducing agents act specifically and alternately (Figure 9c). We conclude that $\mathrm{H}_{2} \mathrm{O}_{2}$ oxidizes the thiol groups of the two vicinal cysteine residues within the hinge loop via a mono-sulfenic acid derivative into a disulfide bridge. Only the wild-type $\alpha 7 \beta 1$ integrin, but not the $\alpha 7 \mathrm{hi} \beta 1$, can be oxidized within its hinge region to result in a disulfide bridge and an extended conformation. With its oxidized thiol-switch, the integrin binds to laminin-111 with stronger signals in the titration-ELISA, in molecular force measurements and in cell adhesion experiments. Noteworthy, the concentrations of $\mathrm{H}_{2} \mathrm{O}_{2}$ applied in protein-chemical experiments were one order of magnitude higher than the ones in cellular experiments. This difference is reasoned by different factors, such as the stoichiometric ratio between the integrin and $\mathrm{H}_{2} \mathrm{O}_{2}$ and sensitivity of the cells against $\mathrm{H}_{2} \mathrm{O}_{2}$. In protein-chemical assays, the molar concentration of isolated $\alpha 7 \beta 1$ integrin is higher than in cell experiments and thus requires higher molar concentrations of $\mathrm{H}_{2} \mathrm{O}_{2}$ to maintain comparable stoichiometric ratios. Various cells can produce cell-membrane-permeable $\mathrm{H}_{2} \mathrm{O}_{2}$ inter alia by the activity of the NADPH-oxidase-4 (NOX4) [54,55]. Previously, we showed that vascular smooth muscle cells transiently form $\mathrm{H}_{2} \mathrm{O}_{2}$ in a NOX4-dependent manner at spatially restricted sites [22]. These redox hot spots coincide with cell protrusions, where cells take the first contact with the extracellular matrix during the initial step of cell adhesion. They are transient, and $\mathrm{H}_{2} \mathrm{O}_{2}$ production ceases after cells have established an initial adhesive contact [22]. Here, we also demonstrated that extracellular Trx1 may reduce the thiol-switch within the integrin. It reduces the disulfide bond within the integrin $\alpha 7$ hinge region and converts the fully active integrin into the less active bent conformation (Figure 9b). This may lead to less firm cell attachment or even detachment.

In the Trx1 system, electrons are donated from NADPH to the flavo- and selenoprotein Trx reductase that reduces the oxidoreductase Trx1. Trx 1 itself reduces disulfides and single cysteine modifications in several substrate proteins, e.g., nuclear factor $\kappa B$ and peroxiredoxins (reviewed in [32]). Both Trx1 and Trx reductase are reportedly secreted by various cells [56,57] and belong to the scarcely occurring and not yet well-characterized extracellular reducing agents [32]. Extracellular Trx1 redox regulates immune mediators and signal-transmitting ion channels [58], such as macrophage migration inhibitory factor (MIF) [59], tumor necrosis factor receptor superfamily member 8/CD30 [60] and the transient receptor potential channel 5 (TRPC5) [59]. Our study adds a new substrate, integrin $\alpha 7 \beta 1$, to 
the list of redox-regulated Trx1 substrates and most likely also other integrins which are crucial for the adhesive and migratory interaction and signal transduction between cells and the ECM.

In summary, extracellular $\operatorname{Tr} x 1$ and $\mathrm{H}_{2} \mathrm{O}_{2}$ constitute parts of a redox-regulation circuit which regulates integrin $\alpha 7 \beta 1$ via its hinge-located thiol switch and thus affects initial steps of integrin-mediated cell adhesion (Figure 9c). Extracellular Trx1 and $\mathrm{H}_{2} \mathrm{O}_{2}$ activate and attenuate, respectively, integrin-binding activity. Such alternating changes of high and lower ligand-binding activities of integrins likely are necessary for migration, where cells attach at the front and detach at the rear. Thus, the local abundance and ratio of these oxidizing and reducing agents in the extracellular space redox-regulate integrins with functional consequences on their force exertion and cell migration. Worthwhile in this respect, the $\alpha$ 7hi $\beta 1$-expressing cells do not form force-transmitting lamellipodia but bleb-like cell protrusions on laminin-111, implying that redox-regulated integrin activity might even change the mode of cellular migration.

\section{Conclusions}

Here, we showed that, in contrast to the structurally relevant disulfide bonds, the cysteine pair Cys604-Cys610 within the integrin $\alpha 7$ hinge region is a reversible thiol-switch, which determines the conformation and laminin-binding activity of integrins on both the molecular and cellular level. It can be regulated by micromolar concentrations of $\mathrm{H}_{2} \mathrm{O}_{2}$ and by extracellular Trx1, both of which are cell-produced mediators of redox regulation and thus signaling molecules for integrin-mediated cell migration. This may be a physiological redox-regulation circuit on the surface of cells during cell attachment and detachment, two basic steps in cell migration, where the integrin ectodomains mediate the force-transmitting and signal-conveying interaction with the extracellular matrix.

Author Contributions: Conceptualization, J.A.E. and E.-M.H.; methodology, L.B., J.G., J.M. and G.P.; software, C.W., A.K., M.M. and G.P.; validation and formal analysis, C.W., A.K., M.M., G.P., E.-M.H. and J.A.E.; investigation, L.B., J.G., J.M., C.H., M.F.C., C.W., A.K. and M.M.; resources, M.R. and D.V.; data curation, L.B., J.G. and J.M.; writing—original draft preparation, J.A.E.; writing—review and editing, J.A.E., L.B., J.M. and E.-M.H.; visualization, L.B., J.G., J.M., J.A.E. and M.M.; supervision, J.A.E.; project administration, J.A.E.; funding acquisition, J.A.E. and E.-M.H. All authors have read and agreed to the published version of the manuscript.

Funding: J.A.E. and E.-M.H. received financial support from the Deutsche Forschungsgemeinschaft (DFG grants Eb177/14-1 and Ha 8334/2-2 within the cooperative DFG program SPP1710: Dynamics of Thiol-based Redox Switches in Cellular Physiology). J.A.E. received funding from the Medical Faculty of the University of Münster within the IZKF program (IZKF-grant: Ebl2/014/16). In addition, J.A.E. and D.V. received funding through the SFB1009: Breaking Barriers-Program from the Deutsche Forschungsgemeinschaft (DFG grants: SFB1009 project A09 and SFB1009 project A01, respectively).

Acknowledgments: We thank Lea Herzog for her help in mutating the integrin $\alpha 7$ cDNA. We acknowledge Felix Schmalbein for technical support of producing and purifying recombinant integrin ectodomains. We thank A. Sonnenberg (Netherlands Cancer Institute, Amsterdam) for providing GoH3 antibodies. We thank the staff in the BioEM Lab, C-CINA, University of Basel, and the Core Facility for Integrated Microscopy (CFIM), Panum Institute, University of Copenhagen, for providing excellent electron microscopy facilities. We thank Carola Alampi (C-CINA), Mohamed Chami (C-CINA) and Klaus Qvortrup (CFIM) for practical help with electron microscopy.

Conflicts of Interest: The authors declare no conflict of interest. 


\section{Appendix A}

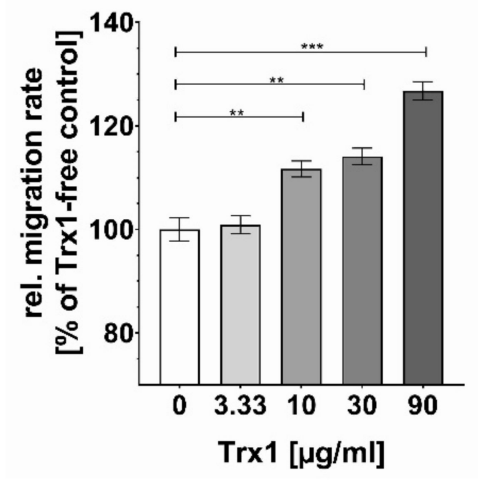

Figure A1. In a dose-dependent manner, reduced Trx1 promotes chemohaptotactic migration of non-transfected HT1080 cells toward poly-L-lysine in an integrin-independent manner. The bottom face of a CIM-plate was coated with 0.01 poly-L-lysine at $4{ }^{\circ} \mathrm{C}$ overnight. A group of $5 \times 10^{4} /$ well non-transfected HT1080 cells was allowed to migrate in the presence of different concentrations of reduced Trx1. The $\Delta$ cell index values were monitored. From them, relative $\Delta \Delta$ cell index values were calculated. Means \pm SD of triplicates from a representative experiment out of three experiments are shown. Significance levels: ${ }^{* *} p \leq 0.01 ;{ }^{* * *} p \leq 0.005$

\begin{tabular}{|c|c|}
\hline & \\
\hline & PLSLEETDCYRVDIDRGANVQKESKENQWLGVSVRSQGPGGKIVTCAHRYESRQRVD \\
\hline 121 & ETRDVIGRCFVLSQDLAIRDELDGGEWKFCEGRPQGHEQFGFCQQGTAATFSPDSHYI \\
\hline 31 & " \\
\hline & EELSFVAGAPRANHKGAVVILRKDSASRLIPEVVLSGERLTSGFGYSL \\
\hline 01 & LIVGAPYFFERQEELGGAVYVYMNQGGHWADISPLRICGSPDSMFGISLA \\
\hline 61 & PDIAVGAPFDGDGKVFIYHGSSLGVVVKPSQVLEGEAVGIKSFGYSLSGGLDVDGNH \\
\hline 21 & PDLLVGSLADTAALFRARPVLHVSQEIFIDPRAIDLE'QPNCADGRLVCVDIK \\
\hline 8. & JPSSYSPSVALDYMLDGDTDRRLRGQVPRVTFLSRGLDDLRHQSSGTVWLKHQHDRVCGD \\
\hline & VFQLQENVKDKLRA IVVTLSYGLRTPPLGRQAPGQELPTVAP ILNAHQPSTQRTE IHF \\
\hline & GGEDKICQSNLQLERYQFCSRISDTEFQALPMDLDGRTALFALSGQPFIGLELTVT \\
\hline & LPSDPARPQADGDDAHEAQLLVTLPASLRYSGVRALDSVEKPLC \\
\hline & IKRGAQVTFYLILS \\
\hline & FSGEVKGESAMRSERDVGSKVKYEVTVSNQGQSLNTLGSAFLNIMWPHEIANG \\
\hline & WLLYPMRVELEGGQGPGKRGICSPRPNILQLDVDSRDRRRRELGQPEPQEPPEKVEPSTS \\
\hline & WWPVSSAEKRNVTLDCAQGTAKCVVFSCPLYSFDRAAVLHVWGRLWNSTFLEEYMAVKSL \\
\hline & EVIVRANI TVKSS I KNLLLRDASTVI PVMVYLDPMAVVVEGVPWWVILLAVLA GLLVLAL \\
\hline & LVLLLWKLGFFKRAKHPEATVPQYHAVK I PREDRQQFKEEKTGT IQRSNWGNSQWEGSDA \\
\hline & \\
\hline
\end{tabular}

Figure A2. Mass-spectrometric analysis of proteins trapped by Trx1-trap mutant. The Cys-X-X-Ser mutant of Trx1 was applied in an intermediate trapping approach to trap Trx1 substrates on $\alpha 7 \mathrm{wt}-\mathrm{HT} 1080$ cells. The trapped proteins were analyzed after tryptic digestion, using liquid chromatography coupled with mass spectrometry. Among the trapped proteins, integrin $\alpha 7$ was identified with a MaxQuant score of 22.9 with three individual peptides (marked in red). All three peptides were identified at a 2+ charge state, with individual MaxQuant scores of 76.5 (AIDLEQPNCADGR, PEP 1.1 E-7), 44.9 (LIPEVVLSGER, PEP 0.0027) and 36.7 (SEELSFVAGAPR, PEP 0.0055). The two cysteines of the hinge motif are highlighted with black boxes.

\section{References}

1. Aumailley, M. The laminin family. Cell Adh. Migr. 2013, 7, 48-55. [CrossRef] [PubMed]

2. Rodriguez, M.L.; Graham, B.T.; Pabon, L.M.; Han, S.J.; Murry, C.E.; Sniadecki, N.J. Measuring the contractile forces of human induced pluripotent stem cell-derived cardiomyocytes with arrays of microposts. J. Biomech. Eng. 2014, 136, 051005. [CrossRef] [PubMed]

3. Campbell, I.D.; Humphries, M.J. Integrin structure, activation, and interactions. Cold Spring Harb. Perspect. Biol. 2011, 3. [CrossRef] [PubMed] 
4. Humphries, J.D.; Byron, A.; Humphries, M.J. Integrin ligands at a glance. J. Cell Sci. 2006, 119, 3901-3903. [CrossRef]

5. Su, Y.; Xia, W.; Li, J.; Walz, T.; Humphries, M.J.; Vestweber, D.; Cabanas, C.; Lu, C.; Springer, T.A. Relating conformation to function in integrin alpha5beta1. Proc. Natl. Acad. Sci. USA 2016, 113, E3872-E3881. [CrossRef] [PubMed]

6. Askari, J.A.; Tynan, C.J.; Webb, S.E.; Martin-Fernandez, M.L.; Ballestrem, C.; Humphries, M.J. Focal adhesions are sites of integrin extension. J. Cell Biol. 2010, 188, 891-903. [CrossRef]

7. Lenter, M.; Uhlig, H.; Hamann, A.; Jeno, P.; Imhof, B.; Vestweber, D. A monoclonal antibody against an activation epitope on mouse integrin chain b1 blocks adhesion of lymphocytes to the endothelial integrin alpha 6 beta 1. Proc. Natl. Acad. Sci. USA 1993, 90, 9051-9055. [CrossRef]

8. Humphries, J.D.; Chastney, M.R.; Askari, J.A.; Humphries, M.J. Signal transduction via integrin adhesion complexes. Curr. Opin. Cell Biol. 2018, 56, 14-21. [CrossRef]

9. Horton, E.R.; Humphries, J.D.; James, J.; Jones, M.C.; Askari, J.A.; Humphries, M.J. The integrin adhesome network at a glance. J. Cell Sci. 2016, 129, 4159-4163. [CrossRef]

10. Thomas, J.R.; Paul, N.R.; Morgan, M.R. Adhesion and growth factor receptor crosstalk mechanisms controlling cell migration. Essays Biochem. 2019, 63, 553-567. [CrossRef]

11. Eble, J.A.; Wucherpfennig, K.W.; Gauthier, L.; Dersch, P.; Krukonis, E.; Isberg, R.R.; Hemler, M.E. Recombinant soluble human a3b1 integrin: Purification, processing, regulation, and specific binding to laminin-5 and invasin in a mutually exclusive manner. Biochemistry 1998, 37, 10945-10955. [CrossRef] [PubMed]

12. Eble, J.A.; Bruckner, P.; Mayer, U. Vipera lebetina venom contains two disintegrins inhibiting laminin-binding b1 integrins. J. Biol. Chem. 2003, 278, 26488-26496. [CrossRef] [PubMed]

13. Nishiuchi, R.; Takagi, J.; Hayashi, M.; Ido, H.; Yagi, Y.; Sanzen, N.; Tsuji, T.; Yamada, M.; Sekiguchi, K. Ligand-binding specificities of laminin-binding integrins: A comprehensive survey of laminin-integrin interactions using recombinant a3b1, a6b1, a7b1 and a6b4 integrins. Matrix Biol. 2006, 25, 189-197. [CrossRef] [PubMed]

14. Mayer, U.; Saher, G.; Fassler, R.; Bornemann, A.; Echtermeyer, F.; Von Der Mark, H.; Miosge, N.; Poschl, E.; von der Mark, K. Absence of integrin a7 causes a novel form of muscular dystrophy. Nat. Genet. 1997, 17, 318-323. [CrossRef] [PubMed]

15. Werner, A.; Willem, M.; Jones, L.L.; Kreutzberg, G.W.; Mayer, U.; Raivich, G. Impaired axonal regeneration in a7 integrin-deficient mice. J. Neurosci. 2000, 20, 1822-1830. [CrossRef]

16. Haas, T.L.; Sciuto, M.R.; Brunetto, L.; Valvo, C.; Signore, M.; Fiori, M.E.; Di Martino, S.; Giannetti, S.; Morgante, L.; Boe, A.; et al. Integrin a7 Is a Functional Marker and Potential Therapeutic Target in Glioblastoma. Cell Stem Cell 2017, 21, 35-50.e39. [CrossRef]

17. Oikawa, Y.; Hansson, J.; Sasaki, T.; Rousselle, P.; Domogatskaya, A.; Rodin, S.; Tryggvason, K.; Patarroyo, M. Melanoma cells produce multiple laminin isoforms and strongly migrate on a5 laminin(s) via several integrin receptors. Exp. Cell Res. 2011, 317, 1119-1133. [CrossRef]

18. Ziober, B.L.; Chen, Y.Q.; Ramos, D.M.; Waleh, N.; Kramer, R.H. Expression of the a7b1 laminin receptor suppresses melanoma growth and metastatic potential. Cell Growth Differ. 1999, 10, 479-490.

19. Eble, J.A.; De Rezende, F.F. Redox-relevant aspects of the extracellular matrix and its cellular contacts via integrins. Antioxid. Redox Signal. 2014, 20, 1977-1993. [CrossRef]

20. Grosche, J.; Meissner, J.; Eble, J.A. More than a syllable in fib-ROS-is: The role of ROS on the fibrotic extracellular matrix and on cellular contacts. Mol. Aspects Med. 2018, 63, 30-46. [CrossRef]

21. Goitre, L.; Pergolizzi, B.; Ferro, E.; Trabalzini, L.; Retta, S.F. Molecular Crosstalk between Integrins and Cadherins: Do Reactive Oxygen Species Set the Talk? J. Signal Transduct. 2012, 2012, 807682. [CrossRef] [PubMed]

22. de Rezende, F.F.; Martins Lima, A.; Niland, S.; Wittig, I.; Heide, H.; Schroder, K.; Eble, J.A. Integrin a7b1 is a redox-regulated target of hydrogen peroxide in vascular smooth muscle cell adhesion. Free Radic. Biol. Med. 2012, 53, 521-531. [CrossRef] [PubMed]

23. Boronat, S.; Domenech, A.; Hidalgo, E. Proteomic Characterization of Reversible Thiol Oxidations in Proteomes and Proteins. Antioxid. Redox Signal. 2017, 26, 329-344. [CrossRef] [PubMed]

24. Zhang, K.; Pan, Y.; Qi, J.; Yue, J.; Zhang, M.; Xu, C.; Li, G.; Chen, J. Disruption of disulfide restriction at integrin knees induces activation and ligand-independent signaling of a4b7. J. Cell Sci. 2013, 126, 5030-5041. [CrossRef] 
25. Yue, J.; Pan, Y.; Sun, L.; Zhang, K.; Liu, J.; Lu, L.; Chen, J. The unique disulfide bond-stabilized W1 b4-b1 loop in the a 4 b-propeller domain regulates integrin a4b7 affinity and signaling. J. Biol. Chem. 2013, 288, 14228-14237. [CrossRef]

26. Laragione, T.; Bonetto, V.; Casoni, F.; Massignan, T.; Bianchi, G.; Gianazza, E.; Ghezzi, P. Redox regulation of surface protein thiols: Identification of integrin a 4 as a molecular target by using redox proteomics. Proc. Natl. Acad. Sci. USA 2003, 100, 14737-14741. [CrossRef]

27. Passam, F.; Chiu, J.; Ju, L.; Pijning, A.; Jahan, Z.; Mor-Cohen, R.; Yeheskel, A.; Kolsek, K.; Tharichen, L.; Aponte-Santamaria, C.; et al. Mechano-redox control of integrin de-adhesion. Elife 2018, 7. [CrossRef]

28. Mor-Cohen, R. Disulfide Bonds as Regulators of Integrin Function in Thrombosis and Hemostasis. Antioxid. Redox Signal. 2016, 24, 16-31. [CrossRef]

29. Leader, A.; Mor-Cohen, R.; Ram, R.; Sheptovitsky, V.; Seligsohn, U.; Rosenberg, N.; Lahav, J. The role of protein disulfide isomerase in the post-ligation phase of b3 integrin-dependent cell adhesion. Thromb. Res. 2015, 136, 1259-1265. [CrossRef]

30. Levin, L.; Zelzion, E.; Nachliel, E.; Gutman, M.; Tsfadia, Y.; Einav, Y. A single disulfide bond disruption in the b3 integrin subunit promotes thiol/disulfide exchange, a molecular dynamics study. PLoS ONE 2013, 8, e59175. [CrossRef]

31. Sun, Q.H.; Liu, C.Y.; Wang, R.; Paddock, C.; Newman, P.J. Disruption of the long-range GPIIIa Cys(5)-Cys(435) disulfide bond results in the production of constitutively active GPIIb-IIIa (aIlbb3) integrin complexes. Blood 2002, 100, 2094-2101. [CrossRef] [PubMed]

32. Hanschmann, E.M.; Godoy, J.R.; Berndt, C.; Hudemann, C.; Lillig, C.H. Thioredoxins, glutaredoxins, and peroxiredoxins-molecular mechanisms and health significance: From cofactors to antioxidants to redox signaling. Antioxid. Redox Signal. 2013, 19, 1539-1605. [CrossRef] [PubMed]

33. Yi, M.C.; Khosla, C. Thiol-Disulfide Exchange Reactions in the Mammalian Extracellular Environment. Annu. Rev. Chem. Biomol. Eng. 2016, 7, 197-222. [CrossRef] [PubMed]

34. Livak, K.J.; Schmittgen, T.D. Analysis of relative gene expression data using real-time quantitative PCR and the 2(-DDC(T)) Method. Methods 2001, 25, 402-408. [CrossRef]

35. Eble, J.A. Titration ELISA as a Method to Determine the Dissociation Constant of Receptor Ligand Interaction. J. Vis. Exp. 2018. [CrossRef]

36. Urbainsky, C.; Nolker, R.; Imber, M.; Lubken, A.; Mostertz, J.; Hochgrafe, F.; Godoy, J.R.; Hanschmann, E.M.; Lillig, C.H. Nucleoredoxin-Dependent Targets and Processes in Neuronal Cells. Oxid. Med. Cell. Longev. 2018, 2018, 4829872. [CrossRef]

37. Godoy, J.R.; Funke, M.; Ackermann, W.; Haunhorst, P.; Oesteritz, S.; Capani, F.; Elsasser, H.P.; Lillig, C.H. Redox atlas of the mouse. Immunohistochemical detection of glutaredoxin-, peroxiredoxin-, and thioredoxin-family proteins in various tissues of the laboratory mouse. Biochim. Biophys. Acta 2011, 1810, 2-92. [CrossRef]

38. Grube, L.; Dellen, R.; Kruse, F.; Schwender, H.; Stuhler, K.; Poschmann, G. Mining the Secretome of C2C12 Muscle Cells: Data Dependent Experimental Approach To Analyze Protein Secretion Using Label-Free Quantification and Peptide Based Analysis. J. Proteome Res. 2018, 17, 879-890. [CrossRef]

39. Navdaev, A.; Lochnit, G.; Eble, J.A. The rhodocetin alphabeta subunit targets GPIb and inhibits von Willebrand factor induced platelet activation. Toxicon Off. J. Int. Soc. Toxinology 2011, 57, 1041-1048. [CrossRef]

40. Krokhin, O.V.; Cheng, K.; Sousa, S.L.; Ens, W.; Standing, K.G.; Wilkins, J.A. Mass spectrometric based mapping of the disulfide bonding patterns of integrin a chains. Biochemistry 2003, 42, 12950-12959. [CrossRef]

41. Calvete, J.J. Structures of integrin domains and concerted conformational changes in the bidirectional signaling mechanism of allbb3. Exp. Biol. Med. 2004, 229, 732-744. [CrossRef] [PubMed]

42. Xiong, J.P.; Stehle, T.; Diefenbach, B.; Zhang, R.; Dunker, R.; Scott, D.L.; Joachimiak, A.; Goodman, S.L.; Arnaout, M.A. Crystal structure of the extracellular segment of integrin aVb3. Science 2001, 294, 339-345. [CrossRef] [PubMed]

43. Lahav, J.; Wijnen, E.M.; Hess, O.; Hamaia, S.W.; Griffiths, D.; Makris, M.; Knight, C.G.; Essex, D.W.; Farndale, R.W. Enzymatically catalyzed disulfide exchange is required for platelet adhesion to collagen via integrin a2b1. Blood 2003, 102, 2085-2092. [CrossRef] [PubMed]

44. Blouin, E.; Halbwachs-Mecarelli, L.; Rieu, P. Redox regulation of b2-integrin CD11b/CD18 activation. Eur. J. Immunol. 1999, 29, 3419-3431. [CrossRef] 
45. Verhaar, R.; Dekkers, D.W.; De Cuyper, I.M.; Ginsberg, M.H.; De Korte, D.; Verhoeven, A.J. UV-C irradiation disrupts platelet surface disulfide bonds and activates the platelet integrin aIlbb3. Blood 2008, 112, 4935-4939. [CrossRef]

46. Liu, S.Y.; Tsai, M.Y.; Chuang, K.P.; Huang, Y.F.; Shieh, C.C. Ligand binding of leukocyte integrin very late antigen-4 involves exposure of sulfhydryl groups and is subject to redox modulation. Eur. J. Immunol. 2008, 38, 410-423. [CrossRef]

47. Hemler, M.E.; Huang, C.; Takada, Y.; Schwarz, L.; Strominger, J.L.; Clabby, M.L. Characterization of the cell surface heterodimer VLA-4 and related peptides. J. Biol. Chem. 1987, 262, 11478-11485.

48. Mor-Cohen, R.; Rosenberg, N.; Peretz, H.; Landau, M.; Coller, B.S.; Awidi, A.; Seligsohn, U. Disulfide bond disruption by a b3-Cys549Arg mutation in six Jordanian families with Glanzmann thrombasthenia causes diminished production of constitutively active allbb3. Thromb. Haemost. 2007, 98, 1257-1265.

49. Arjonen, A.; Alanko, J.; Veltel, S.; Ivaska, J. Distinct recycling of active and inactive b1 integrins. Traffic 2012, 13, 610-625. [CrossRef]

50. Boye, K.; Ligezowska, A.; Eble, J.A.; Hoffmann, B.; Klosgen, B.; Merkel, R. Two barriers or not? Dynamic force spectroscopy on the integrin a7b1 invasin complex. Biophys. J. 2013, 105, 2771-2780. [CrossRef]

51. Kong, F.; Garcia, A.J.; Mould, A.P.; Humphries, M.J.; Zhu, C. Demonstration of catch bonds between an integrin and its ligand. J. Cell Biol. 2009, 185, 1275-1284. [CrossRef] [PubMed]

52. Paul, C.D.; Mistriotis, P.; Konstantopoulos, K. Cancer cell motility: Lessons from migration in confined spaces. Nat. Rev. Cancer 2017, 17, 131-140. [CrossRef] [PubMed]

53. Ruprecht, V.; Wieser, S.; Callan-Jones, A.; Smutny, M.; Morita, H.; Sako, K.; Barone, V.; Ritsch-Marte, M.; Sixt, M.; Voituriez, R.; et al. Cortical contractility triggers a stochastic switch to fast amoeboid cell motility. Cell 2015, 160, 673-685. [CrossRef] [PubMed]

54. Amanso, A.; Lyle, A.N.; Griendling, K.K. NADPH Oxidases and Measurement of Reactive Oxygen Species. Methods Mol. Biol. 2017, 1527, 219-232. [CrossRef]

55. Guo, S.; Chen, X. The human Nox4: Gene, structure, physiological function and pathological significance. J. Drug Target. 2015, 23, 888-896. [CrossRef] [PubMed]

56. Rubartelli, A.; Bajetto, A.; Allavena, G.; Wollman, E.; Sitia, R. Secretion of thioredoxin by normal and neoplastic cells through a leaderless secretory pathway. J. Biol. Chem. 1992, 267, 24161-24164. [PubMed]

57. Soderberg, A.; Sahaf, B.; Rosen, A. Thioredoxin reductase, a redox-active selenoprotein, is secreted by normal and neoplastic cells: Presence in human plasma. Cancer Res. 2000, 60, 2281-2289.

58. Leveillard, T.; Ait-Ali, N. Cell Signaling with Extracellular Thioredoxin and Thioredoxin-Like Proteins: Insight into Their Mechanisms of Action. Oxid. Med. Cell. Longev. 2017, 2017, 8475125. [CrossRef]

59. Son, A.; Kato, N.; Horibe, T.; Matsuo, Y.; Mochizuki, M.; Mitsui, A.; Kawakami, K.; Nakamura, H.; Yodoi, J. Direct association of thioredoxin-1 (TRX) with macrophage migration inhibitory factor (MIF): Regulatory role of TRX on MIF internalization and signaling. Antioxid. Redox Signal. 2009, 11, 2595-2605. [CrossRef]

60. Schwertassek, U.; Balmer, Y.; Gutscher, M.; Weingarten, L.; Preuss, M.; Engelhard, J.; Winkler, M.; Dick, T.P. Selective redox regulation of cytokine receptor signaling by extracellular thioredoxin-1. EMBO J. 2007, 26, 3086-3097. [CrossRef]

(C) 2020 by the authors. Licensee MDPI, Basel, Switzerland. This article is an open access article distributed under the terms and conditions of the Creative Commons Attribution (CC BY) license (http://creativecommons.org/licenses/by/4.0/). 